\title{
Microwave sintering of porous Ti-Nb-HA composite with high strength and enhanced bioactivity for implant applications
}

\begin{abstract}
In the present study, high order porous $\mathrm{Ti}-\mathrm{Nb}(50-\mathrm{x})-\mathrm{HA}(\mathrm{x})(\mathrm{x}=0,10,20 \mathrm{wt}$. \%) composites have been fabricated for orthopedic application by using powder metallurgical route consisting temporary space alloying and rapid microwave sintering process. Structural porosity, elastic modulus, compressive strength, corrosion resistance, and in-vitro bioactivity of as-sintered Ti$\mathrm{Nb}-\mathrm{HA}$ composites were studied. Results showed that the reinforcement of the HA assists in the formation of structural porosity, which reduced the elastic modulus. Porous Ti-Nb (with HA 10$20 \%$ content) composite possessed $40-60 \%$ structural porosity with a pore size of 150-260 $\mu \mathrm{m}$ and exhibited elastic modulus in the range of 12.5 - $29 \mathrm{GPa}$ (near to human bone 8-20 GPa), which overcome the problem of stress shielding. The as-sintered composite not only possessed low elastic modulus but also exhibit high compressive strength (205-395 MPa). The alloying of $\mathrm{HA}$ improved the corrosion resistance and the protective efficiency of Ti-40Nb-10HA and Ti$30 \mathrm{Nb}-20 \mathrm{HA}$ composites was measured $40 \%$ and $72 \%$, respectively higher than the $\mathrm{Ti}-\mathrm{Nb}$ composite. In-vitro biological evaluation tests confirmed that the developed composites are noncytotoxic and porous structure provides a vehicle for cell adhesion and growth. Moreover, various biocompatible phases such as $\mathrm{Ca}_{3}\left(\mathrm{PO}_{4}\right)_{2}$ (known as TCP), $\mathrm{Ti}_{5} \mathrm{P}_{3}$ and $\mathrm{CaO}$ were developed, which helped in cell proliferation and differentiation. High biological activities were found on the Ti-30Nb-20HA composite have when compared with the Ti-Nb and Ti-40Nb-10HA composite and could be used as a potential biomaterial for the various possible orthopedic applications.
\end{abstract}

Keywords: Porous implant, Titanium composite, Hydroxyapatite; Rapid microwave sintering; Elastic modulus, Compressive strength.

\section{Introduction}

Titanium (Ti) and its alloys are the perspectives and ultimate choice for the biomedicalimplants due to their exceptional biomechanical integrity and great bio-activity [1]. The requirement of orthopedic implants demands near-to-bone elastic modulus and high strength [2]. However, the relatively high elastic modulus of Ti-composite (110GPa) compared to bone (1020GPa) leads to stress-shielding that impedes bone remodeling and results in bone resorption and implantation failed [3]. To deal with these limitations, there is the only solution is to fabricate porous $\beta$-type Ti alloys/composites with appropriate porosity attributes [4]. The stiffness of Ticomposite could be limited through inculcating structural porosity that also results in the low elastic modulus [5-6]. Moreover, it has been reported that formation of a $\beta$-phase crystalline structure with stabilizing elements (such as $\mathrm{Nb}$ and $\mathrm{Sn}$ ) reduces the elastic modulus of $\mathrm{Ti}$ composite to about $40 \mathrm{GPa}$ [7-11]. Indeed, a porous structure is one of the key ideas to control the 
issues of stress shielding as well as provide suitable conditions for the promotion of tissue around the implant [12]. The shape, size, and percentage of structural porosity affect the biomechanical functionalities of implants made up of alloys/composites [13]. A well-connected porous architecture (51-52\%) with pore size in the range of 97-294 $\mu \mathrm{m}$ was found viable and potential for bone tissue formation. The requirement for better manufacturing designs and strategies are increasing day-by-day to produce porous structure, rather than dense, and to transform $\alpha$-Ti to $\beta$-Ti microstructure, with tailored mechanical properties [14-16]. A number of $\beta$-type Ti-alloys/composites were fabricated using various $\mathrm{HA}$ and other stabilizing elements such as Ti-HA [17-19], Ti-Nb [20-23], Ti-Nb-Zr [23-24], Ti-Sn-Nb [25-26], Ti-Ni [27-28], TiNb-Zr-x(HA) [29], Ti-Nb-HA [30], and Ti-Nb-Ta-Zr-xHaP [31]. Among these materials, the HA and $\mathrm{Nb}$-based Ti-alloys have attracted much scientific interest for the development of orthopedic implants, because these possessed low elastic modulus and high content of $\mathrm{HA}$ and $\mathrm{Nb}$ element improved the corrosion resistance of composite [17, 28-30]. Hydroxyapatite (HA, $\left.\mathrm{Ca}_{10}\left(\mathrm{PO}_{4}\right)_{6}(\mathrm{OH})_{2}\right)$ was used, as an alloying element, promotes the osseointegration, bioactivity and accelerate the bone in-growth support provided by the implant [17-19]. The powder metallurgy $(\mathrm{PM})$ route is one of the most widely used technologies for developing porous implants owing to its cost-effectiveness, control over the pore architecture (size and density), morphology, and capability of producing near-net shapes [32]. The PM consists element alloying of metallic-powders and subsequent sintering of alloyed powder-mixture for customization of material composition, mechanical properties, and architecture geometry [32-34]. To customize and regulate the pore characteristics (shape, size, and percentage) and biomechanical integrity, numerous temporary space holders materials such as Sodium chloride, carbamide, sugar pellets, tapioca, saccharose, magnesium powder, and ammonium hydrogen carbonate $\left(\mathrm{NH}_{4} \mathrm{HCO}_{3}\right)$ have been used [12,13,35].

Previously, various technique/methodologies have been employed to fabricate/synthesize porous Ti-based alloys/composites, including additive manufacturing techniques (selective laser sintering and electron beam sintering) [36-37], powder metallurgy methods (conventional sintering in vacuum, argon, hot isostatic sintering [38], self-propagating high-temperature synthesis [39-40], spark plasma sintering [41]),solid-state foaming by expansion of argon bubbles [42] and continuous zone melting with hydrogen gas evolution during solidification, etc [43]. However, these techniques have a few disadvantages in terms of high temperature and long sintering time. Further, these parameters influence the uniformity of the microstructure and usually result in coarse grain growth that counters the mechanical properties and biomedical performances [44]. Recently, the application of microwave sintering (MS) process for the sintering of uniformly controlled microstructure and porosity of Ti-based composite has been reported [45]. The heating gradient such as heating temperature, rate of temperature rise, and time determines the microstructure and grain growth [46, 47]. The process of heating in the microwave involves electromagnetic energy that in a later stage is quickly transformed into heat, owing to which, fine grain growth and a uniform microstructure are easy to obtain along with densified compact and lower porosity defect [48-51]. These days microwave sintering is under 
consideration for the sintering of metallic and ceramic powder for biomedical and other industrial applications [52-54].

Choy et al. synthesized porous Ti-CaP composites using mechanical alloying (MA) and MS process for biomedical application. They found that while sintering of the composite composition, HA formed beta-tricalcium phosphate ( $\beta$-TCP) and calcium titanate $\left(\mathrm{CaTiO}_{3}\right)$. Further, it was reported that the as-fabricated composites were highly porous (pore size up to 152 $\mu \mathrm{m}$ ) and mechanically strong (compressive strength and modulus of $212 \mathrm{MPa}$ and $12 \mathrm{GPa}$, respectively) [55]. Moreover, the observed mechanical properties and the bone-like apatite growth on the Ti-CaP composite confirmed their implications in the orthopedic industry [56]. Bovand et al. synthesized Ti-HA $x(x=10-30 \%)$ composite by microwave sintering process and effect of HA content on structural porosity and hardness of composite were studied. Higher content of HA increased the porosity and hardness of the composite [57]. Biomimetic low elastic porous Ti-6Al-4V/TiC/HA composite was developed by the MA and MS process for biomedical application. The developed composite exhibited a $27 \%$ porous structure, $93 \mathrm{MPa}$ compressive strength, and 556HV micro-hardness, which is potentially used for a load-bearing application [58]. $\mathrm{Xu}$ et al. fabricated porous Ni-Ti shape memory composite through MS technique and studied the effect of pore size on the microstructure, mechanical properties, and corrosion resistance characteristics of the structures [59]. The application of MS for the synthesis of Ti-Nb shape memory composite has been reported and parametric optimization of microwave process has been carried out to enhance the mechanical properties of the sintered composite. Xu et al. fabricated porous Ti-15MO composite by PM and MS process and achieved 16-50\% porosity. It was reported that the high degree of structural porosity decreased the mechanical properties of the composite [60].

From the available literature, very limited studies have been reported on microwave sintering and temporary space alloying for the development of Ti-based composites. In the present research work, highly porous low elastic Ti-Nb-HA $(\mathrm{HA}=0,10$ and 20) with high strength and enhanced bioactivity was fabricated using powder metallurgical technique consisting temporary space alloying and rapid microwave sintering. In this work, extensive efforts have been made to get insights of the effect of pore size and porosity on the structural morphology, compressive strength, elastic modulus, corrosion resistance, and bioactivity of as-developed composites.

\section{Materials and Method}

\subsection{Preparation of porous Ti-Nb-HA Composites}

Powder of titanium-Ti ( $99 \%$ purity, $\leq 25 \mu \mathrm{m})$, niobium- $\mathrm{Nb}(99 \%$ purity, $\leq 25 \mu \mathrm{m})$, and hydroxyapatite-HA $(99 \%$ purity, $\leq 2 \mu \mathrm{m})$ were procured from Intelligent Materials Private Limited, India and used to synthesize Ti_Nb-HA composite. Fig. 1 shows the morphology of raw powder before blending. The powders were mixed according to the desired composition of Ti 50 $\% \mathrm{wt}, \mathrm{Nb} 50-\mathrm{HA} \% \mathrm{wt}$, and $\mathrm{HA} \% \mathrm{wt}(\mathrm{HA}=0,10$ and 20). The powder mixture was blended in the high energy planetary ball mill (Fritsch, Pulverisette 7) using tungsten carbide vial and balls, as 
per the process adopted in previous research work [61-63]. The powder-to-balls ratio was 1:10. The blending of the composite composition was performed at $200 \mathrm{rpm}$ for about $12 \mathrm{hrs}$ at ambient conditions. For avoiding powder's agglomeration and cold welding, $2 \%$ stearic acid was added to the mixture.

After blending, 20 wt. \% sieved urea $\left(\mathrm{CO}\left(\mathrm{NH}_{2}\right)_{2}\right)$ powder particles of size in the range of 45 $200 \mu \mathrm{m}$ as a temporary space holding materials were mixed in the blended powder mixture to control the structural porosity in the composites. Table 1 shows the pore characteristics of $\mathrm{Ti}-\mathrm{Nb}-$ HA composite regarding urea powder mesh size. After that, the blended powder/urea mixture was uniaxially pressed at $300 \mathrm{MPa}$ load under hydraulic press in a die to obtain a green compact of size diameter $20 \mathrm{~mm}$ and $10 \mathrm{~mm}$ thick. The green compact was submerged in water to dissolve urea pellets for 6-8 hrs and continuous stirring was carried out using magnetic stirrer. After complete dissolution of urea pellet, the green compact was sintered by the rapid microwave sintering process. Sintering of compact has been carried out by microwave sintering process, as per the process reported [62]. Experimental set-up for rapid microwave sintering process has been developed in-house using domestic IFB-microwave of $25 \mathrm{~L}$ capacity $(1400 \mathrm{~W}, 2.45 \mathrm{~Hz})$. The sintering was carried out for $5 \mathrm{~min}$ and surface temperature was reached to $1500^{\circ} \mathrm{C}$, as recorded by the pyrometer. Fig. 2 presents the schematic diagram of the in-house developed experimental setup of the rapid microwave sintering process. Fig. 3 presents the process steps for the synthesis of Ti-Nb-HA Composite and also presents the sintered dense and porous Composites. Fig. 4 presents the mechanism of sintering of powder particles and have unique advantages over conventional sintering and other sintering techniques. During microwave sintering, materials absorb microwave energy and then transform into heat within the sample volume due to rapid oscillation of dipoles at microwave frequencies and sintering of materials can be occurred quickly.

\subsection{Testing and characterization of porous $\mathrm{Ti}-\mathrm{Nb}-\mathrm{HA}$ Composites}

After sintering, the microstructure, morphology, elemental, phase composition, structural porosity, and mechanical properties of the sintered $\mathrm{Ti}_{50} \mathrm{Nb}_{50-\mathrm{x}} \mathrm{HA}_{x}$ Composite were studied in details. The field emission scanning electron microscopy (FE-SEM-7600F; make: JEOL) and energy dispersive spectroscopy (EDS) were used for the morphological and elemental composition investigations. Further, x-ray diffraction (XRD; make/model: X'pert-PRO), was used for the phase composition evaluation at a setting of $\mathrm{CuK} \alpha$ radiation $\sim 45 \mathrm{kV}$, current intensity $\sim 40 \mathrm{~mA}$, incident radiation $\sim 2 \theta$. The structural porosity percentage $(\mathrm{P})$ was determined using the formula:

$$
P=\left(1-\frac{m}{v} * \rho\right) * 100
$$

Where, $\mathrm{m}, v$, and $\rho$ are the mass, volume, and theoretical density of the sintered Composite, respectively. 
The compressive strength and elastic modulus of the sintered composites were determined using a compression test. Cylindrical specimens of dimension $5 \times 10 \mathrm{~mm}$ (diameter $\times$ height) were cut form sintered Composites. Uniaxial compression test was conducted at room temperature on the hydraulic UTM (Model-25, Tinius Olsen) testing machine at $0.05 \mathrm{~mm} / \mathrm{min}$. The elastic modulus was calculated from the initial stage of the stress vs. strain plot with the help of extensometer. The change in length was recorded with the help of software.

The investigation on the corrosion characteristics of developed Composites was analyzed through potentiodynamic polarization testing by using an electrochemical system (Gamry 1000E, Warminster, USA) in simulated body fluids (SBF) consisting of $9 \mathrm{~g} / \mathrm{l}$ of $\mathrm{NaCl}$ as well as small volumetric fractions of $\mathrm{CaCl}_{2}(0.24 \mathrm{~g} / \mathrm{l}), \mathrm{KCl}(0.43 \mathrm{~g} / \mathrm{l})$, and $\mathrm{NaHCO}_{3}(0.2 \mathrm{~g} / \mathrm{l})$. The $\mathrm{pH}$ value of the resulting solution was observed as 7.2. In testing, fabricated specimens and saturated-carmolelectrode (SCE) were treated as work and reference electrodes, whereas, graphite rod has been treated as a counter electrode. All the observations were made at room $\left(37^{\circ} \mathrm{C}\right)$ under the physiological environmental condition as reported in previous studies [38-39]. In the Tafel method, tangents are drawn on a plot of $E$ (potential) vs. $\log I$ (current). Upon extrapolation of the tangents, the latter intersect at a point corresponding to the corrosion potential $\left(E_{\text {Corr }}\right)$, which can then be correlated to the corrosion current $\left(I_{\text {Corr }}\right)$ on the $x$-axis. The corrosion rate was determined using the Tafel extrapolation method as per ASTM standard G 102 - 89. Faraday's Law was used to calculate the corrosion rate as per the following equation:

$$
\text { Corrosion Rate }(\mathrm{CR})=\mathrm{K}_{1} \frac{\mathrm{i}_{\text {corr }}}{\rho} \mathrm{EW}
$$

Whereas, $K_{1}=3.27 \times 10^{-3}, \mathrm{~mm} \mathrm{~g} / \mu \mathrm{A} \mathrm{cm} \mathrm{yr}, \rho=$ density in $\mathrm{g} / \mathrm{cm}^{3}$, and $\mathrm{EW}=$ Equivalent weight. The protective efficiency $\left(\mathrm{P}_{\mathrm{i}}\right)$ in percentage was evaluated by using the following equation:

$$
P_{i}=\left[1-\left(\frac{I_{\text {Corr }}}{I_{0 \text { Corr }}}\right)\right] \times 100
$$

Whereas, the $\mathrm{I}_{\text {Corr }}$ indicates the corrosion current density of as-sintered $\mathrm{Ti}-\mathrm{Nb}$ composite (without $\mathrm{HA}$ content) and $\mathrm{I}_{0 \mathrm{Corr}}$ indicates the corrosion current density of as-sintered composites with HA (Ti-40Nb-10HA and Ti-30Nb-20HA). The bioactivity and biological response of assintered Ti-Nb-HA (HA $=0,10,20)$ composites were evaluated by in-vitro cell culture technique.

For cell culture, the specimen of dimension $5 \mathrm{~mm}$ in diameter and $3 \mathrm{~mm}$ thick sample was obtained from the sintered composites and placed in 96 well plates. The MG-63 human osteoblastic cell line was utilized in this study and seeded onto the specimens at a density of $1 \times 10^{5}$ cells $/ \mathrm{cm}^{2}$. The seeded cells on the as-sintered Ti-Nb-HA composites were incubated at $37^{\circ} \mathrm{C}$ in a $5 \mathrm{vol} \% \mathrm{CO}_{2}$ atmosphere in the presence of DMEM supplemented with $10 \%$ bovine serum and 1 vol $\%$ penicillin. The visual examination of cell attachment and growth was investigated by Olympus microscope. The cell number grown and attached on the composites' 
surface was counted using hemocytometer. The cells were trypsinized first, and then centrifuged, and cell numbers were counted under the microscope using hemocytometer. The cell proliferation on the as-sintered Ti-Nb-HA composites was evaluated by MTT assay using 3-(4,5dimethylthiazol-2-yl)-2,5-diphenyltetrazolium bromide based on the conversion of MTT substrate to formazan by viable cells. The rest of the procedural steps are well described in [6163]. The results of the MTT assay were obtained by using an optical density determined at 570nm wavelength. DNA content was also determined for cell proliferation measurements. Acetoxymethyl ester (supplier: Calcein, Molecular Probes, Germany) was used for making live cells and the cell distribution growth on the sample surface was analyzed by using a fluorescent microscope (make: Thornwood, USA). The adherent cells were fixed with paraformaldehyde and permeabilized with Triton X-100 after 48hrs. At incubation periods of 1, 3 and 7 days, the differentiation of the cells, within the conditioned media, was evaluated with the help of cellular alkaline phosphatase-specific activity and osteocalcin content. Alizarin red S staining was carried out to measure the calcium accumulation. Alizarin red $\mathrm{S}$ is a calcium-sensing dye. Differentiated osteoblasts deposit large amounts of extracellular calcium that can be detected by complexing with Alizarin red S. Calcium forms an Alizarin Red S-calcium complex in a chelation process. One mole of Alizarin Red binds to two moles of calcium in an Alizarin Red S-calcium complex. Calcium deposits appear as bright orange-red stained areas. Alizarin red staining $2 \%$ solution dissolved in $0.2 \mathrm{gm}$ alizarin red stain in $10 \mathrm{ml} \mathrm{ddH} 2 \mathrm{O}$, and $\mathrm{pH} 4.2$ with $0.5 \mathrm{M} \mathrm{NaOH}$ was controlled. Cells were removed from wells and washed with D-PBS. Fixative $1 \mathrm{ml}$ of $4 \%$ formaldehyde $(0.4 \mathrm{ml}$ formaldehyde in $9.6 \mathrm{ml}$ PBS) was added in the wells and incubated for a half-hour. Add the fixation solution in $1 \mathrm{ml}$ alizarin red wells and incubate for $30 \mathrm{~min}$. After that stained solution removed and washed the wells with autoclaved ddH2O. The calcium stained areas were investigated under the optical microscope and pictures were recorded for the staining in control C3H10T1/2 cells, osteo-media-induced cells, as well as cells, were grown on the Ti-NbHA composite specimens. The adhesion and morphology of the cells onto the test samples were investigated by FE-SEM (JEOL).

\section{Results and Discussion}

\subsection{Analysis of surface morphology, elemental and phase composition}

The surface morphology, elemental, and phase composition of the three types of composites were investigated corresponding to the HA content by weight percentage $(0,10$, and 20$)$. The structural porosity and pore size depended upon the urea concentration. Fig. 5 shows the average structural porosity and pore size of Ti-Nb-HA composites with different content of urea. The average pore size of porous Ti-Nb-HA composites without urea content was only 25-50 $\mu \mathrm{m}$ only, while with the addition of urea content the pore size increased. The pore size increased from 105 to $265 \mu \mathrm{m}$, when urea content was added from 5 to $20 \%$. With further increase in urea content, the pore size increased more. On the other hand, the average structural porosity of Ti-Nb-HA composites without urea content with was $5-10 \%$, while it increased with the addition of urea 
content. The average structural porosity of Ti-Nb-HA composites increased from 30 to $57 \%$ when urea content was added from 5 to $20 \%$. Concerning published literature, the structural porosity in the range of $30 \%-50 \%$ and pore size $100-350 \mu \mathrm{m}$ are optimal and suitable for the bone tissue ingrowth [12-13]. The obtained results are corroborative with the observed structure of sintered composites. To obtain, high degree of porous structure, $20 \%$ urea content was found suitable and further comparison of sintered composites with HA concentration was carried out. From the SEM micrograph, the highly porous structure was observed in all sintered specimens. Fig. 6(a-b) shows the morphology and associated EDS spectrum of the Ti-Nb composite when no HA content was added. From the SEM micrograph, it can be seen that the structure is highly porous and the average pore size was $100-150 \mu \mathrm{m}$ with structural porosity $30-40 \%$ only. The EDS spectrum analysis revealed that $\mathrm{Ti}$ and $\mathrm{Nb}$ elements were present in the sintered $\mathrm{Ti}-\mathrm{Nb}$ composite, which confirmed that no contamination occurred during element ball milling process. When HA was composite, the open porosities increased in the sited composites. Fig. 6(c-d) shows the morphology and EDS spectrum of Ti-40Nb-10HA composites. A high degree of structural porosity in the range of 40-50\% was obtained and the size of the pores was measured in the range of $150-250 \mu \mathrm{m}$. The EDS spectrum shows the presence of $\mathrm{Ti}$ and $\mathrm{Nb}$ elements along with $\mathrm{Ca}, \mathrm{P}$, and $\mathrm{O}$ elements analysis, which confirm that HA disintegrated at high sintering temperature and compacting pressure. Highly porous composites (Ti-30Nb-20HA) were synthesized, when 20\% HA content reinforced. Fig. 6(e-f) shows the morphology and EDS spectrum of Ti-30Nb-20HA composite. It can be seen that the structure was porous and a high degree of structural porosity (50-60\%) was observed. The size of pores in the synthesized composite was in the range of 200-300 $\mu \mathrm{m}$. The high intensity of Ca and $\mathrm{P}$ in the EDS spectrum confirms the presence of content of HA in the sintered composite. Fig. 7 presents the EDS mapping of the sintered $\mathrm{Ti}-\mathrm{Nb}$ and $\mathrm{Ti}-30 \mathrm{Nb}-20 \mathrm{HA}$ composites. EDS mapping presents the uniform distribution of reinforcement elements in the sintered composites.

Fig. 8 shows the XRD pattern of sintered Ti-Nb-HA $(H A=0,10,20)$ porous composites. The characteristics peaks of $\mathrm{Ti}$ and $\mathrm{Nb} \beta$-phases can be observed in all types of the sintered composite. The XRD pattern of sintered $\mathrm{Ti}-\mathrm{Nb}$ composite presents $\alpha$ - $\mathrm{Ti}, \beta-\mathrm{Ti}$, and $\mathrm{Nb}$ phases only. No other phases were identified. The element $\mathrm{Nb}$ is a $\beta$-phase stabilizer helps the transformation of $\alpha$-Ti to $\beta$-Ti. The element HA is unstable at the high-temperature condition, which leads to crystallographic and morphological changes in the structure. The use of HA content hinders the transformation of $\alpha$-Ti to $\beta$-Ti because HA surrounds the $\mathrm{Ti}$ and $\mathrm{Nb}$ powder particles and leads to lower diffusion rate between reinforcement elements. Form the XRD pattern of Ti-30Nb-20HA sintered composite, it can be seen that the intensity of $\beta$-phases is low as compared to $\mathrm{Ti}-40 \mathrm{Nb}-10 \mathrm{HA}$ and $\mathrm{Ti}-\mathrm{Nb}$ composites. Moreover, at the high sintering temperature, the $\mathrm{HA}$ disintegrated in $\mathrm{Ca}, \mathrm{P}$, and $\mathrm{O}$ elements and formed various biocompatible phases. It was reported that $\mathrm{Ca}_{3}\left(\mathrm{PO}_{4}\right)_{2}, \mathrm{Ti}_{5} \mathrm{P}_{3}$ and $\mathrm{CaO}$ were formed during sintering of $\mathrm{HA}$ with Ti elements to benefit osseointegration performances [15, 29, 30, 31].

\subsection{Mechanical Properties}


Fig. 9 and 10 shows the stress-strain curves of as-sintered porous Ti-Nb-HA composite with different pore size and HA content, respectively. The mechanical properties such as elastic modulus and compression strength of as-fabricated porous Ti-Nb-HA composite depends upon the HA content and structural characteristics integrity (pore size and porosity). The obtained elastic modulus and compression strength from the compressive curves of the as-fabricated porous Ti-Nb-HA composite with pore size, porosity, and HA content, respectively as shown in Fig. 11 and 12. All sintered composite shows similar characteristics and has limited deformation after elastic deformation. In compressive loading, the stress-strain curve shows an early failure of all sintered composite due to a high degree of structural porosity and large pore size. The large pore size acted as notch and crack propagates easily. The mechanical properties such as elastic modulus and compressive strength of sintered composite depended upon the structural porosity and HA content. The compressive strength of the as-fabricated porous Ti-Nb-HA composites was decreased with the increase in pore size.

The compression strength and elastic modulus of the porous Ti-Nb-HA composites vary in the range of 260-455 $\mathrm{MPa}$ and 18-35 GPa, respectively with the content of $\mathrm{HA}$, as can be seen in Fig. 11. The average compression strength of the as-fabricated porous $\mathrm{Ti}-\mathrm{Nb}-0 \% \mathrm{HA}$ composites (when no HA content) was obtained $455 \mathrm{MPa}$. On the other hand, the average compression strength of the as-fabricated porous $\mathrm{Ti}-\mathrm{Nb}-20 \% \mathrm{HA}$ composites (when $20 \% \mathrm{HA}$ content) was obtained $260 \mathrm{MPa}$. The obtained average compression strength (265 MPa) for the as-fabricated porous Ti-Nb-HA composites is close to the compression strength of the human bone (100-230 Mpa for cortical bone and 2-12 MPa for cancellous bone) [12-13]. The average elastic modulus of the as-fabricated porous $\mathrm{Ti}-\mathrm{Nb}-0 \% \mathrm{HA}$ composites (when no HA content) was obtained 35 $\mathrm{GPa}$. On the other hand, the average elastic modulus of the as-fabricated porous $\mathrm{Ti}-\mathrm{Nb}-0 \% \mathrm{HA}$ composites (when $20 \%$ HA content) was obtained $18 \mathrm{GPa}$. The obtained average elastic modulus $(18 \mathrm{GPa})$ for the as-fabricated porous $\mathrm{Ti}-\mathrm{Nb}-20 \% \mathrm{HA}$ composites is close to the elastic modulus of the human bone (3-20 GPa for cortical bone and 0.05-0.5 GPa for cancellous bone)) [12]. With the increase in HA content, the elastic modulus and compressive strength were decreased. This is because HA powder has the small atomic diameter and crystal size, which can easily fill the gap formed between $\mathrm{Ti}$ and $\mathrm{Nb}$ powders and during sintering $\mathrm{HA}$ changed its crystallographic structure and transformed $\beta$-TCP and $\mathrm{CaO}$, thus formed a porous structure and decreased the mechanical characteristics.

The compression strength and elastic modulus of the as-fabricated porous $\mathrm{Ti}-\mathrm{Nb}-\mathrm{HA}$ composites vary in the range of 205-395 $\mathrm{MPa}$ and 15-29 GPa, respectively, with the pore size. The average compression strength of the as-fabricated porous $\mathrm{Ti}-\mathrm{Nb}-\mathrm{HA}$ composites for the pore size 95-105 $\mu \mathrm{m}$ (structural porosity 18-20\%) was obtained $395 \mathrm{MPa}$, as can be seen in Fig. 12. On the other hand, the average compression strength of the as-fabricated porous $\mathrm{Ti}-\mathrm{Nb}-\mathrm{HA}$ composites for the pore size 260-270 $\mu \mathrm{m}$ (structural porosity 53-57\%) was obtained $205 \mathrm{MPa}$. The obtained average compression strength (205 MPa) for the as-fabricated porous $\mathrm{Ti}-\mathrm{Nb}-\mathrm{HA}$ composites is close to the compression strength of the human bone (100-230 Mpa for cortical bone and 2-12 MPa for cancellous bone) [12-13]. The average elastic modulus of the as- 
fabricated porous Ti-Nb-HA composites for the pore size 95-105 $\mu \mathrm{m}$ was obtained $29 \mathrm{GPa}$. On the other hand, the average elastic modulus of the as-fabricated porous Ti-Nb-HA composites for the pore size $260-270 \mu \mathrm{m}$ was obtained $15 \mathrm{GPa}$. The obtained average elastic modulus (15 GPa) for the as-fabricated porous Ti-Nb-HA composites is close to the elastic modulus of the human bone (3-20 GPa for cortical bone and 0.05-0.5 GPa for cancellous bone) [12].

Fig. 13 shows the fractography of fractured $\mathrm{Ti}-30 \mathrm{Nb}-20 \mathrm{HA}$ composite specimens under compressive test with a different pore size $(105,205$, and $265 \mu \mathrm{m})$. Fig. 13(a) shows the fractography of fractured Ti-30Nb-20HA composite specimens at pore size $105 \mu \mathrm{m}$. The failure pattern was observed as cleavage and sharp separation and highlighted by yellow color. The Ti$30 \mathrm{Nb}-20 \mathrm{HA}$ composite specimens at pore size $105 \mu \mathrm{m}$ have thick edge and resist the bending of pore edge. In the beginning, the cracks initiated along the edge of thick pore walls and then form the original cracks. It is because of the thick pore wall can absorb more energy for crack propagation [14]. On the other hand, when pore was increased, the failure mechanism was found slightly different. The failure of Ti-30Nb-20HA composite specimens at pore size $215 \mu \mathrm{m}$ took place at the interface of the pores and edges of the pores. Due to HA and large pore size, the wall of pore strut becomes thin and results in bending at high compressive force. Consequently, the composite failed to owe to the bending of thin pore edges and propagation of cracks on the edges of pore strut. Subsequently, the appearances of macro-cracks in fractured morphology are highlighted by red color, as can be seen in Fig. 13(b). The fractography of fractured Ti-30Nb20HA composite specimens at pore size $265 \mu \mathrm{m}$ can be seen in Fig. 13(c). The specimens have similar failure mechanism was observed as in the case of specimens have pore size $215 \mu \mathrm{m}$. Due large pore size, the wall of pore strut becomes thin and at high compressive force bending takes place and cracks start to propagate at the edges of pore strut.

\subsection{In-vitro corrosion analysis}

The corrosion behavior of as-sintered Ti-Nb-HA composite was analyzed by Tafel extrapolation technique in SBF. Fig. 14 shows the potentiodynamic polarization curve of assintered Ti-Nb-HA composites. All the sintered composite specimens exhibit similar curve characteristics of cathodic and anodic reactions, typical characteristics of the passive performance. The porous sample without HA (Ti-Nb-OHA composite) showed wide steady passive zone, low corrosion current density around $3.75 \mu \mathrm{A} / \mathrm{cm}^{2}$ and corrosion potential ($0.185 \mathrm{~V}$ ) was measured, which indicates the good passivity and corrosion resistance. Using HA was used as reinforcement, the polarization curve slightly shifted towards the lower current density side. The porous Ti-40Nb-10HA composite sample (with 10\% HA) showed more wide steady passive zone as compared to $\mathrm{Ti}-\mathrm{Nb}$ composite and the respective current density and corrosion potential were found as $2.25 \mu \mathrm{A} / \mathrm{cm}^{2}$ and $-0.28 \mathrm{mV}$, respectively. The obtained results indicate that the reinforcement of HA content leads to increase the corrosion resistance. This is because during sintering $\mathrm{HA}$ disintegrated in to $\mathrm{Ca}, \mathrm{P}$, and $\mathrm{O}$ elements and formed various bioceramic phases $\mathrm{Ca}_{3}\left(\mathrm{PO}_{4}\right)_{2}$ (known as TCP), $\mathrm{Ti}_{5} \mathrm{P}_{3}$ and $\mathrm{CaO}$. These bio-ceramic phases promote 
the formation and growth of apatite and thick apatite layer on the composite surface were deposited [12-14, 29]. The increase in the corrosion resistance is owing to the formation of the apatite layer in the porous structure and bio-ceramic oxides, which prevent the surface from degradation and improve the corrosion resistance. The polarization curve for the porous sample of Ti-30Nb-20HA composite was shifted towards the lower current density side and exhibit low current density as compared to $\mathrm{Ti}-\mathrm{Nb}$ and $\mathrm{Ti}-40 \mathrm{Nb}-10 \mathrm{HA}$ composite. In this case, the respective density of the current and corrosion potential was found as $1.05 \mu \mathrm{A} / \mathrm{cm}^{2}$ and $-0.428 \mathrm{mV}$, respectively. The as-sintered Ti-30Nb-20HA composite possessed better and higher corrosion resistance as compared to $\mathrm{Ti}-\mathrm{Nb}$ and $\mathrm{Ti}-40 \mathrm{Nb}-10 \mathrm{HA}$ composite. A similar finding was reported in [12-13], suggesting that reinforcement of HA improved the resistance of corrosion for Ticomposites. Form the obtained results of all sintered specimens; the protective efficiency of Ti$40 \mathrm{Nb}-10 \mathrm{HA}$ and $\mathrm{Ti}-30 \mathrm{Nb}-20 \mathrm{HA}$ composite was measured $40 \%$ and $72 \%$, respectively. It can be concluded that the as-sintered porous Ti-30Nb-20HA composite exhibit high corrosion resistance and potentials and can be used for biomedical applications.

\subsection{Cells Viability \& growth on Ti-Nb-HA Composites}

Fig. 15 shows the effect of pore size (\% porosity) and HA concentration on cell proliferation and differentiation (MTT assay, DNA content, and ALP activity) of MG- 63 cells determined on Days 1, 3, and 7 after seeding on as-synthesized porous Ti-Nb-HA composite samples. All observed data was statically analyzed at a 95\% confidence level using ANOVA, and the individual group was statistically highly significant $(\mathrm{p}<0.001)$ for each treatment (different composite compositions) at different time intervals (days). Fig. 15 (a) and (d) shows the cell growth on the as-synthesized porous Ti-Nb-HA composite samples at different pore size and HA concentration. The cells growth increased with pore size and HA concentration, but higher growth can be seen in the samples of high HA concentration. Hydroxyapatite (HA) promotes the apatite formation and many biological activities such as cytoplasmic extensions, the accusation of filopodia and retraction of an extracellular matrix (ECM). It can be seen that the higher cell density and large numbers were found on the samples having high HA content and large pore size (Ti-Nb-20\%HA sample with $265 \mu \mathrm{m}$ pore size). A high content of HA and porous structure facilitate the formation of bone tissues and promotes the osseointegration process. Assynthesized porous Ti-30Nb-20HA composite specimens possessed a higher cell proliferation rate. This is attributed due to the growth of chamomiles flower petal-like, which enhanced the bone formation process. Moreover, the petal-like microstructure escalated the surface energy, which promoted protein absorption and cell growth. The DNA content on the specimen's surface increased with the increase in the proliferation rate. Fig. 15(b) and (e) shows the DNA content activity on the as-synthesized porous Ti-Nb-HA composite samples at different pore size and HA concentration. The DNA content increased with pore size and HA concentration, but higher DNA content can be seen in the samples of high HA concentration. From the figures, it can be seen that porous Ti-30Nb-20HA composite specimens have a higher proportion of DNA content. Fig. 15(c) and (f) shows the ALP-type differentiation activities of MG-63 cells on the porous Ti- 
30Nb-20HA composite specimens. Many differentiation activities were found in the high HA content and higher differentiation activities were found on Ti-30Nb-20HA composite specimens. The serum level of ALP activity was found significantly higher in the Ti-30Nb-20HA composite specimens, compared with the other composite specimens.

Fig. 16 shows the morphology and distribution of Mg-63 cell lines on the surface of assintered porous Ti-Nb (without $\mathrm{HA}$ ), Ti-40Nb-10HA, and Ti-30Nb-20HA composites after 1 day and 7 days. The green fluorescence shows the fully attached and live viable grown cell on the porous composites. Fig. 16 (a-c) shows the cell attachment and growth after $1^{\text {st }}$ day on the $\mathrm{Ti}-\mathrm{Nb}$, Ti-40Nb-10HA and Ti-30Nb-20HA composites, respectively. The porous Ti-30Nb-20HA composite exhibit higher cell adhesion and spreading as compared to Ti-Nb (without $\mathrm{HA}$ ) and Ti-40Nb-10HA composites. It can be seen that the cell started to aggregate and dispersed layered cells, possessing large nuclei, was observed. Various life activities such as cytoplasmic extensions, redirection of extracellular matrix (ECM), and filopodia accusation were observed, which indicates that the cell grown on all specimens' surfaces. Moreover, an interesting growth pattern of the cells was observed. Further, FE-SEM micrograph confirms the cell attachment of the on as-sintered Ti-Nb-HA composites and observation confirmed that the as-sintered composites proved an ideal surface for the cells attachment. The highly porous structure provides better growth and strong interlocking for better implant stability [58, 62]. Fig. 17 (c-e) shows the attached cells on the as-sintered porous Ti-Nb (without $\mathrm{HA}$ ), Ti-40Nb-10HA, and Ti-30Nb20HA composites after 7 days. The filopodias (red arrows) being extended by some of the growing cells on the surface of the scaffold can be seen from the SEM micrograph. Moreover, variation in the cell growth pattern also potentially suggests osteoconductive character, which warrants additional study. To further reiterate, the viability aspect, the MTT assay was also performed. It can be seen from Fig. 17, the MG-63 cells remained viable when grown on the Ti$\mathrm{Nb}-\mathrm{HA}$ composites. Since the key characteristics of the osteoinductive process are increased mineralization specifically increasing in the calcium laden cells, hence, Alizarin red staining was being exploited to reiterate the observations. As discussed earlier, it was strongly suggested that increased red stain within the cells growing as clusters on the Ti-Nb-HA composites depicted osteoinductive effects of the scaffolds, as can be seen in Fig. 17. These observations thus suggested that $\mathrm{Ti}-\mathrm{Nb}-\mathrm{HA}$ composites possess a strong potential to be osteoinductive when the mesenchymal stem cells are permitted to grow in the presence of these scaffolds. It can be seen that a high degree of cells was observed on the Ti-30Nb-20HA composite as compared to Ti-Nb and Ti-Nb-HA composites. This is because the porous structure and HA content promote the formation of apatite layer which accelerates the osseointegration process. Based on these observations, it is to suggest that Ti-30Nb-20HA composites can be used in orthopedic applications wherein the implanted scaffold may provide biocompatibility with the cells types important in the bone function and possibly regeneration.

\section{Conclusions}


In this study, high order porous $\mathrm{Ti}-\mathrm{Nb}(50-\mathrm{x})-\mathrm{HA}(\mathrm{x})(\mathrm{x}=0,10,20)$ composites were successfully synthesized by a powder metallurgical route consisting of rapid microwave sintering and temporary space alloying/compositing technique. High order structural porosity was achieved, in the range of 50-60\%, by reinforcing of HA content with pore size $105-265 \mu \mathrm{m}$. The porous Ti-Nb-HA composites possessed low elastic modulus of 15-29 GPa (near to human bone 8-20GPa) and high compressive strength (205-395 GPa). It has been found that reinforcement of HA not only helped in inducing the porous structure but also improved the bioactivity. The HA disintegrated and foamed secondary biocompatible phases such as $\mathrm{Ca}_{3}\left(\mathrm{PO}_{4}\right)_{2}, \mathrm{Ti}_{5} \mathrm{P}_{3}$ and $\mathrm{CaO}$, which improved the corrosion resistance of composites. The in-vitro bioactivity results showed that the reinforcement of HA is beneficial to promote tissue growth and osseointegration process. Stronger cell attachment, cell proliferation, and differentiation have been found on the $\mathrm{Ti}-30 \mathrm{Nb}-$ 20HA composite have when compared with the Ti-Nb and Ti-40Nb-10HA composite. Thus, the combination of high order porous structure, connected pores features, reasonable elastic modulus, high compressive strength and enhanced biomedical performances of $\mathrm{Ti}-\mathrm{Nb}-\mathrm{HA}$ composites make it a potential candidate for implants.

\section{Conflict of Interest}

The authors have declared no conflict of interest.

\section{References}

[1]. M. Geetha, A.K. Singh, R. Asokamani, A.K. Gogia, Ti-based biomaterials, the ultimate choice for orthopedic implants-a review. Progress in materials science 54 (2009)s 397425.

[2]. M. Niinomi, M. Nakai, J. Hieda, Development of new metallic Composites for biomedical applications. Acta biomaterials 8 (2012) 3888-3903.

[3]. C. Prakash, H.K. Kansal, B.S. Pabla, S. Puri, A. Aggarwal, Electric discharge machining-A potential choice for surface modification of metallic implants for orthopedic applications: A review. Proceedings of the Institution of Mechanical Engineers, Part B: Journal of Engineering Manufacture 230 (2016) 331-353.

[4]. C. Torres-Sanchez, J. McLaughlin, A. Fotticchia, Porosity and pore size effect on the properties of sintered Ti35Nb4Sn Composite scaffolds and their suitability for tissue engineering applications. Journal of Alloys and Compounds 731 (2018) 189-199.

[5]. M.R. Raza, A.B. Sulong, N. Muhamad, M.N. Akhtar, J. Rajabi, Effects of binder system and processing parameters on formability of porous Ti/HA composite through powder injection molding. Materials \& Design 87 (2015) 386-392.

[6]. G. Ryan, A. Pandit, D.P. Apatsidis, Fabrication methods of porous metals for use in orthopaedic applications. Biomaterials 27 (2006) 2651-2670.

[7]. T.K. Jung, H. Matsumoto, T. Abumiya, N. Masahashi, M.S. Kim, S. Hanada, Mechanical properties-graded $\mathrm{Ti}$ Composite implants for orthopedic applications. In Materials Science Forum 631 (2010) 205-210. 
[8]. Y.L. Hao, S.J. Li, S.Y. Sun, R. Yang, Effect of $\mathrm{Zr}$ and Sn on Young's modulus and superelasticity of Ti-Nb-based Composites. Materials Science and Engineering: A 441 (2006) 112-118.

[9]. S.J. Li, T.C. Cui, Y.L. Hao, R. Yang, Fatigue properties of a metastable $\beta$-type titanium Composite with reversible phase transformation. Acta biomaterialia 4 (2008) 305-317.

[10]. F. Sun, Y.L. Hao, S. Nowak, T. Gloriant, P. Laheurte, F. Prima, A thermo-mechanical treatment to improve the superelastic performances of biomedical $\mathrm{Ti}-26 \mathrm{Nb}$ and $\mathrm{Ti}-$ $20 \mathrm{Nb}-6 \mathrm{Zr}$ (at.\%) Composites. Journal of the mechanical behavior of biomedical materials 4 (2011) 1864-1872.

[11]. J.A. Davidson, A.K. Mishra, P. Kovacs, R.A. Poggie, New surface-hardened, lowmodulus, corrosion-resistant Ti-13Nb-13Zr Composite for total hip arthroplasty. Biomedical materials and engineering 4 (1994) 231-243.

[12]. L. Zhang, Z.Y. He, Y.Q. Zhang, Y.H. Jiang, R. Zhou, Rapidly sintering of interconnected porous Ti-HA biocomposite with high strength and enhanced bioactivity. Materials Science and Engineering: C 67 (2016) 104-114.

[13]. J. L. Xu, Bao, L. Z., Liu, A. H., Jin, X. F., Luo, J. M., Zhong, Z. C. and Zheng, Y. F. Effect of pore sizes on the microstructure and properties of the biomedical porous NiTi Composites prepared by microwave sintering. Journal of Alloys and Compounds 645 (2015) 137-142.

[14]. L. Zhang, Zhang, Y. Q., Jiang, Y. H., and Zhou. R. Superelastic behaviors of biomedical porous NiTi Composite with high porosity and large pore size prepared by spark plasma sintering. Journal of Alloys and Compounds 644 (2015) 513-522.

[15]. A. Bandyopadhyay, F. Espana, V.K. Balla, S. Bose, Y. Ohgami, N.M. Davies, Influence of porosity on mechanical properties and in vivo response of Ti6Al4V implants, Acta Biomater. 6 (2010) 1640-1648.

[16]. L.G. Hou, L. Li, Y.F. Zheng, Fabrication and characterization of porous sintered Ti-Ag compacts for biomedical application purpose, J. Mater. Sci. Technol. 29 (2013) 330-338.

[17]. A. Arifin, A.B. Sulong, N. Muhamad, J. Syarif, M.I. Ramli, Powder injection molding of HA/Ti6Al4V composite using palm stearin as based binder for implant material. Materials \& Design 65 (2015) 1028-1034.

[18]. M.J. Rastgoo, M. Razavi, E. Salahi, I. Mobasherpour, Sprak plasma sintering behavior of hydroxyapatite-titanium nano-composite. Journal of the Australian Ceramic Society 53 (2017) 449-455.

[19]. S. Salman, O. Gunduz, S. Yilmaz, M.L. Öveçoğlu, M.L. Snyder, S. Agathopoulos, F.N. Oktar, Sintering effect on mechanical properties of composites of natural hydroxyapatites and titanium. Ceramics International 35 (2007) 2965-2971.

[20]. I. Lindemann, R. Schmidt, S. Pilz, B. Gebel, A. Teresiak, A. Gebert, Ultrafine-grained Ti-40Nb prepared by reactive milling of the elements in hydrogen. Journal of Alloys and Compounds 729 (2017) 1244-1249.

[21]. Y.L. Hao, S.J. Li, S.Y. Sun, R. Yang, Effect of Zr and Sn on Young's modulus and superelasticity of Ti-Nb-based Composites. Materials Science and Engineering: A 441 (2006) 112-118.

[22]. S. Guo, Q. Meng, X. Zhao, Q. Wei, H. Xu, Design and fabrication of a metastable $\beta$-type titanium Composite with ultralow elastic modulus and high strength. Scientific Reports 5 (2015) 14688. 
[23]. F. Sun, Y.L. Hao, S. Nowak, T. Gloriant, P. Laheurte, F. Prima, A thermo-mechanical treatment to improve the superelastic performances of biomedical $\mathrm{Ti}-26 \mathrm{Nb}$ and $\mathrm{Ti}-$ $20 \mathrm{Nb}-6 \mathrm{Zr}$ (at.\%) Composites. Journal of the mechanical behavior of biomedical materials 4 (2011) 1864-1872.

[24]. J.A. Davidson, A.K. Mishra, P. Kovacs, R.A. Poggie, New surface-hardened, lowmodulus, corrosion-resistant $\mathrm{Ti}-13 \mathrm{Nb}-13 \mathrm{Zr}$ Composite for total hip arthroplasty. Biomedical materials and engineering 4 (1994) 231-243.

[25]. A. Nouri, P.D. Hodgson, C.E. Wen, Effect of process control agent on the porous structure and mechanical properties of a biomedical $\mathrm{Ti}-\mathrm{Sn}-\mathrm{Nb}$ Composite produced by powder metallurgy. Acta biomaterialia 6 (2010) 1630-1639.

[26]. J. Xiong, Y. Li, X. Wang, P. Hodgson, C.E. Wen, Mechanical properties and bioactive surface modification via alkali-heat treatment of a porous $\mathrm{Ti}-18 \mathrm{Nb}-4 \mathrm{Sn}$ Composite for biomedical applications. Acta biomaterialia 4 (2008) 1963-1968.

[27]. D.S. Li, Y.P. Zhang, X. Ma, X.P. Zhang, Space-holder engineered porous NiTi shape memory Composites with improved pore characteristics and mechanical properties. Journal of Composites and compounds 474 (2009) L1-L5.

[28]. M. Köhl, T. Habijan, M. Bram, H.P. Buchkremer, D. Stöver, M. Köller, Powder metallurgical near- net- shape fabrication of porous NiTi shape memory Composites for use as long- term implants by the combination of the metal injection molding process with the space- Holder technique. Advanced Engineering Materials 11 (2009) 959-968.

[29]. Y.H. He, Y.Q. Zhang, Y.H. Jiang, R. Zhou, Effect of HA (Hydroxyapatite) content on the microstructure, mechanical and corrosion properties of (Ti13Nb13Zr)-xHA biocomposites synthesized by sparkle plasma sintering. Vacuum 131 (2016) 176-180.

[30]. R. Singh, B.P. Singh, A. Gupta, C. Prakash, Fabrication and characterization of Ti-NbHA Composite by mechanical Compositeing and spark plasma sintering for hard tissue replacements. In IOP Conference Series: Materials Science and Engineering 225 (2017) 012051.

[31]. B. Bhushan, A. Singh, R. Singh, J.S. Mehta, A. Gupta, C. Prakash, Fabrication and Characterization of a New Range of $\beta$-type Ti-Nb-Ta-Zr-xHaP $(x=0,10)$ Composite by Mechanical Alloying and Spark Plasma Sintering for Biomedical Applications. Material Today: Proceeding (2018).

[32]. N. Sharma, K. Kumar, Mechanical characteristics and bioactivity of porous Ni50- $x$ Ti50Cu x ( $\mathrm{x}=0,5$ and 10) prepared by P/M. Materials Science and Technology 34 (2018) 934-944.

[33]. B. Sharma, S.K. Vajpai, K. Ameyama, Microstructure and properties of beta Ti-Nb Composite prepared by powder metallurgy route using titanium hydride powder. Journal of Alloys and Compounds 656 (2016) 978-986.

[34]. J.Y. Xiong, Y.C. Li, X.J. Wang, P.D. Hodgson, C.E. Wen, Titanium-nickel shape memory Composite foams for bone tissue engineering. Journal of the mechanical behavior of biomedical materials 1 (2008) 269-273.

[35]. B. Zhao, A.K. Gain, W. Ding, L. Zhang, X. Li, and Y. Fu, A review on metallic porous materials: pore formation, mechanical properties, and their applications. The International Journal of Advanced Manufacturing Technology 95 (2018) 2641-2659.

[36]. I.V. Shishkovsky, L.T. Volova, M.V. Kuznetsov, Y.G. Morozovc, I.P. Parkin, Porous biocompatible implants and tissue scaffolds synthesized by selective laser sintering from Ti and NiTi, J. Mater. Chem. 18 (2008) 1309-1317. 
[37]. P. Bartolo, J.P. Kruth, J. Silva, et al., Biomedical production of implants by additive electro-chemical and physical processes, CIRP Ann.-Manuf. Technol. 61 (2012) 635655.

[38]. S.L. Zhu, X.J. Yang, F. Hu, S.H. Deng, Z.D. Cui, Processing of porous TiNi shape memory Composite from elemental powders by Ar-sintering. Materials Letters 58 (2004) 2369-2373.

[39]. B. Yuan, C.Y. Chung, X.P. Zhang, M.Q. Zeng, M. Zhu, Control of porosity and superelasticity of porous NiTi shape memory Composites prepared by hot isostatic pressing. Smart materials and structures 14 (2005) S201.

[40]. G. Tosun, L. Ozler, M. Kaya, N. Orhan, A study on microstructure and porosity of NiTi Composite implants produced by SHS. Journal of Alloys and Compounds 487 (2009) 605-611.

[41]. Y. Zhao, M. Taya, Y. Kang, A. Kawasaki, Compression behavior of porous NiTi shape memory Composite. Acta materialia 53 (2005) 337-343.

[42]. M. Sugiyama, S.K. Hyun, M. Tane, H. Nakajima, Fabrication of lotus-type porous NiTi shape memory Composites using the continuous zone melting method and tensile property, High Temp. Mater. Proc. 26 (2007) 297-301.

[43]. Y.P. Zhang, B. Yuan, M.Q. Zeng, C.Y. Chung, X.P. Zhang, High porosity and large pore size shape memory Composites fabricated by using poreforming agent $(\mathrm{NH} 4 \mathrm{HCO} 3)$ and capsule-free hot isostatic pressing, J. Mater. Proc. Technol. 192 (2007) 439-442.

[44]. S. Singh, D. Gupta, V. Jain, A.K. Sharma, Microwave processing of materials and applications in manufacturing industries: a review. Materials and Manufacturing Processes 30 (2015) 1-29.

[45]. C.Y. Tang, C.T. Wong, L.N. Zhang, M.T. Choy, T.W. Chow, K.C. Chan, Q. Chen, In situ formation of Ti Composite/TiC porous composites by rapid microwave sintering of Ti6Al4V/MWCNTs powder. Journal of Alloys and Compounds 557 (2013) 67-72.

[46]. A. Mondal, A. Upadhyaya, D. Agrawal, Microwave sintering of W-18Cu and W-7Ni$3 \mathrm{Cu}$ Composites. Journal of Microwave Power and Electromagnetic Energy 43 (2008) 11-16.

[47]. C. Padmavathi, A. Upadhyaya, D. Agrawal, Effect of sintering temperature and heating mode on consolidation of $\mathrm{Al}-7 \mathrm{Zn}-2 \cdot 5 \mathrm{Mg}-1 \mathrm{Cu}$ aluminum Composite. Bulletin of Materials Science 35 (2012) 823-832.

[48]. K.P.P. Pluck, D.S. Wilkinson, Microstructural characterization of a microwave-sintered silicon nitride based ceramic. Journal of materials research 10 (1995) 1387-1396.

[49]. A. Mondal, D. Agrawal, A. Upadhyaya, Microwave sintering of refractory metals/Composites: W, Mo, Re, W-Cu, W-Ni-Cu and W-Ni-Fe Composites. Journal of Microwave Power and Electromagnetic Energy 44 (2010) 28-44.

[50]. M. Oghbaei, O. Mirzaee, Microwave versus conventional sintering: A review of fundamentals, advantages and applications. Journal of Composites and compounds 494 (2010) 175-189.

[51]. D.D. Upadhyaya, P. Ram, Microwave processing of ceramic materials. In Proceedings of DAE-BRNS national symposium on recent trends in electro and magnetoceramics (1999).

[52]. J.K. Han, H.Y. Song, F. Saito, B.T. Lee, Synthesis of high purity nano-sized hydroxyapatite powder by microwave-hydrothermal method. Materials chemistry and physics 99 (2006) 235-239. 
[53]. L. Sha, Y. Liu, Q. Zhang, M. Hu, Y. Jiang, Microwave-assisted co-precipitation synthesis of high purity $\beta$-tricalcium phosphate crystalline powders. Materials Chemistry and Physics 129 (2011) 1138-1141.

[54]. C.Y. Tang, L.N. Zhang, C.YT. Wong, K.C. Chan, T.M. Yue, Fabrication and characteristics of porous NiTi shape memory Composite synthesized by microwave sintering. Materials Science and Engineering: A 528 (2011), 6006-6011.

[55]. M.T. Choy, C.Y. Tang, Effect of Porosity on Compressive Yield Strength of Microwave Sintered Titanium Components. Key Engineering Materials 626 (2014).

[56]. M.T. Choy, C.Y. Tang, L. Chen, W.C. Law, C.P. Tsui, W.W. Lu, Microwave assisted-in situ synthesis of porous titanium/calcium phosphate composites and their in vitro apatiteforming capability. Composites Part B: Engineering 83 (2015) 50-57.

[57]. D. Bovand, M. Yousefpour, S. Rasouli, S. Bagherifard, N. Bovand, A. Tamayol, Characterization of Ti-HA composite fabricated by mechanical Compositeing. Materials \& Design 65 (2015) 447-453.

[58]. M.T. Choy, C.Y. Tang, L. Chen, C.T. Wong, C.P. Tsui, In vitro and in vivo performance of bioactive Ti6Al4V/TiC/HA implants fabricated by a rapid microwave sintering technique. Materials Science and Engineering: C 42 (2014) 746-756.

[59]. J. Xu, J. Zhang, L. Bao, T. Lai, J. Luo, Y. Zheng, Preparation and bioactive surface modification of the microwave sintered porous Ti-15Mo Composites for biomedical application. Science China Materials 1-12 (2018).

[60]. Xu, J., Zhang, J., Bao, L., Lai, T., Luo, J. and Zheng, Y., 2018. Preparation and bioactive surface modification of the microwave sintered porous Ti-15Mo alloys for biomedical application. Science China Materials, pp.1-12.

[61]. C. Prakash, S. Singh, K. Verma, S.S. Sidhu, S. Singh, Synthesis and characterization of Mg-Zn-Mn-HA composite by spark plasma sintering process for orthopedic applications. Vacuum 155 (2018) 578-584.

[62]. C. Prakash, S. Singh, B.S. Pabla, S.S. Sidhu, M.S. Uddin, Bio-inspired low elastic biodegradable Mg-Zn-Mn-Si-HA Composite fabricated by spark plasma sintering. Materials and Manufacturing Processes (2018) 1-12.

[63]. C. Prakash, S. Singh, M. Gupta, M. Mia, G. Królczyk, N. Khanna, Synthesis, Characterization, Corrosion Resistance and In-Vitro Bioactivity Behavior of Biodegradable $\mathrm{Mg}-\mathrm{Zn}-\mathrm{Mn}-(\mathrm{Si}-\mathrm{HA}) \quad$ Composite for Orthopaedic Applications. Materials 11 (2018) 1602. 

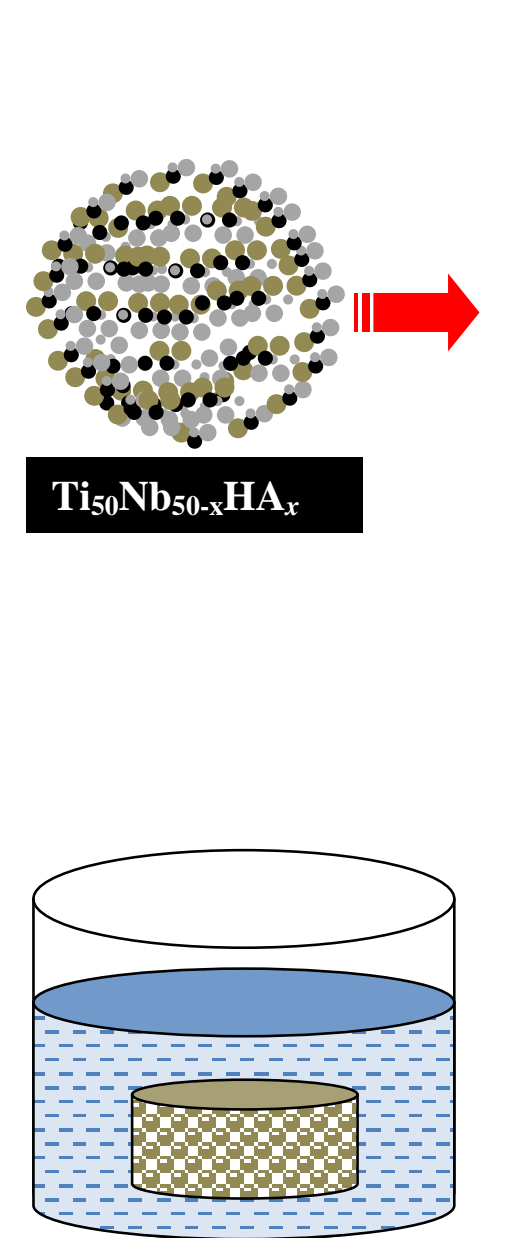

De-alloying of space holder

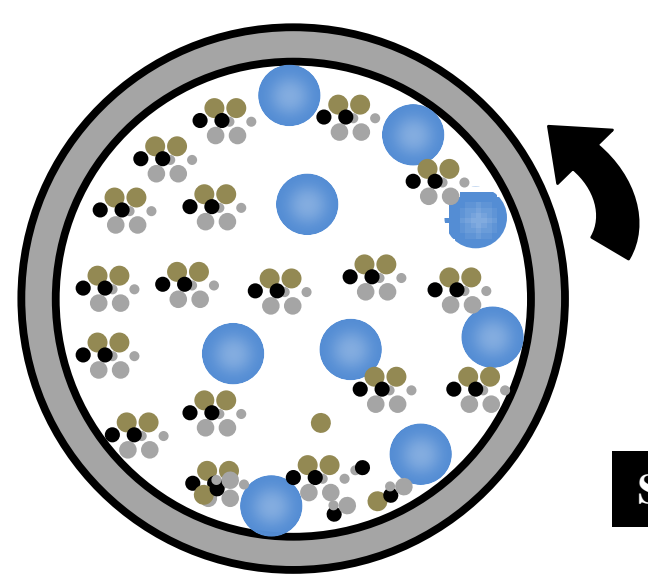

Mechanical Alloying

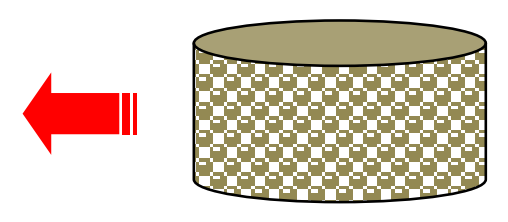

Green compact
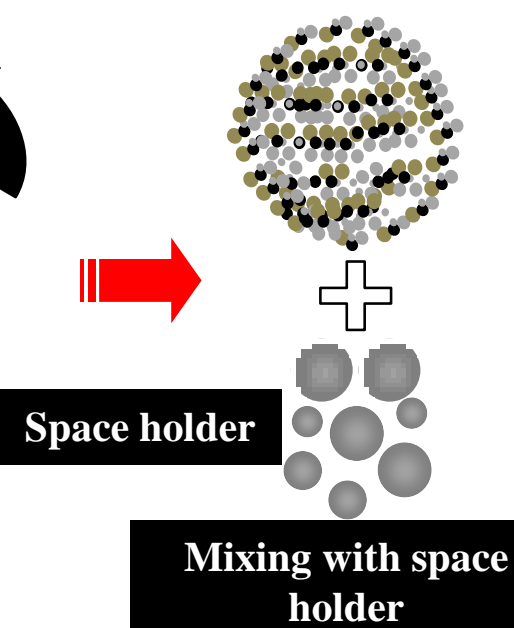

holder
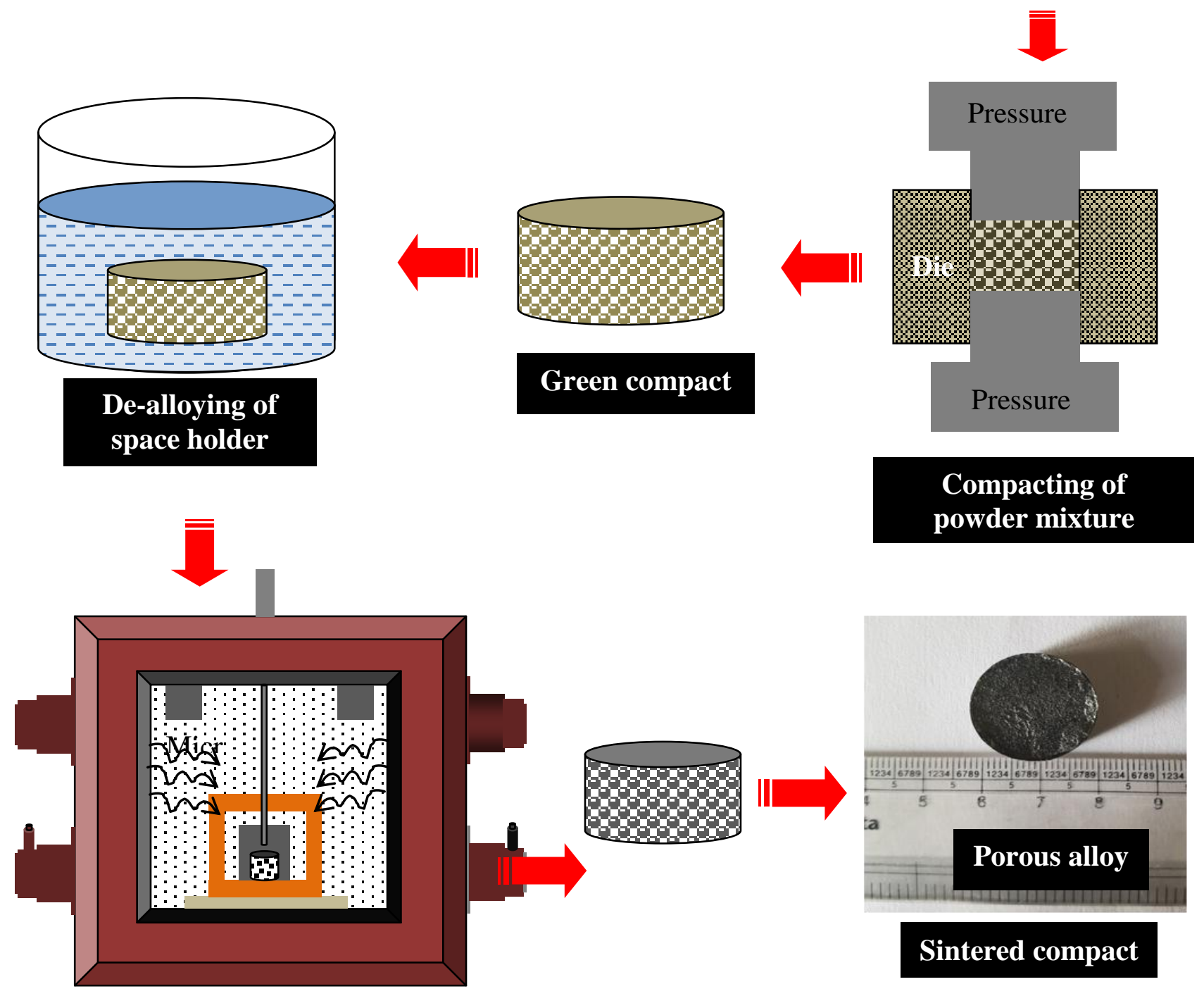

Sintered compact

Rapid Microwave sintering 


\section{Highlights}

- The high order porous composites have been fabricated for biomedical applications.

- The developed composites possessed reasonable mechanical characteristics which can overcome the problem of stress shielding.

- The composites showed sufficient corrosion resistance and biocompatibility.

- The results of the developed composites witnessed cell proliferation and differentiation. 
Tabel 1. Pore characteristics of Ti-Nb-HA composite with reference to urea powder mesh size

\begin{tabular}{ccc}
\hline Urea particle size $(\boldsymbol{\mu m})$ & Porosity $(\boldsymbol{\%})$ & Average pore size $(\boldsymbol{\mu m})$ \\
\hline 200 Mesh $(\leq 74 \mu \mathrm{m})$ & $18-20 \%$ & $105 \mu \mathrm{m}$ \\
120 Mesh $(\leq 125 \mu \mathrm{m})$ & $25-29 \%$ & $155 \mu \mathrm{m}$ \\
60 Mesh $(\leq 250 \mu \mathrm{m})$ & $45-48 \%$ & $225 \mu \mathrm{m}$ \\
45 Mesh $(\leq 354 \mu \mathrm{m})$ & $53-57 \%$ & $265 \mu \mathrm{m}$ \\
\hline
\end{tabular}



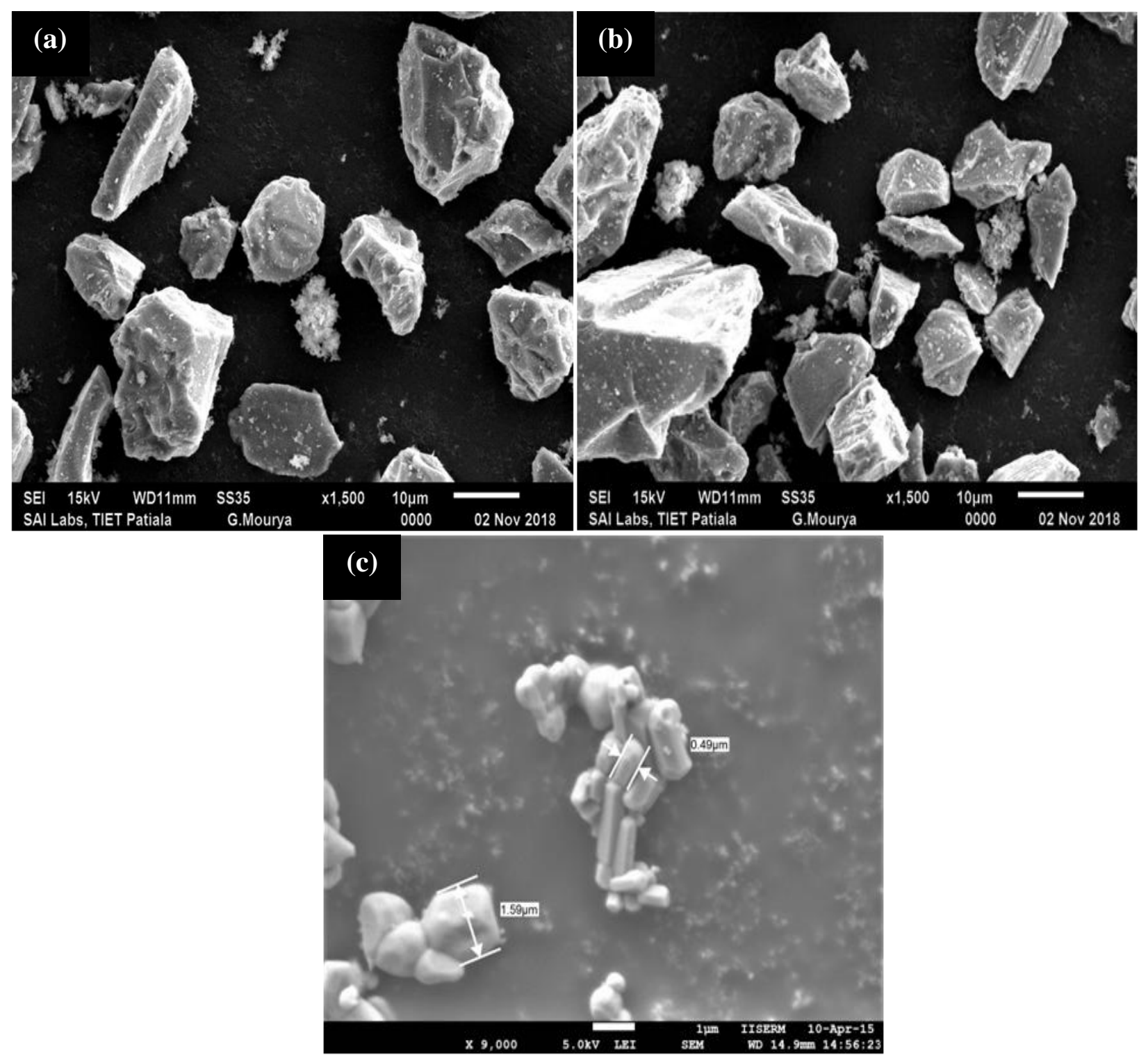

Fig. 1. SEM micrograph of raw powders before mechanical alloying (a) Ti, (b) Nb, and (c) HA. 


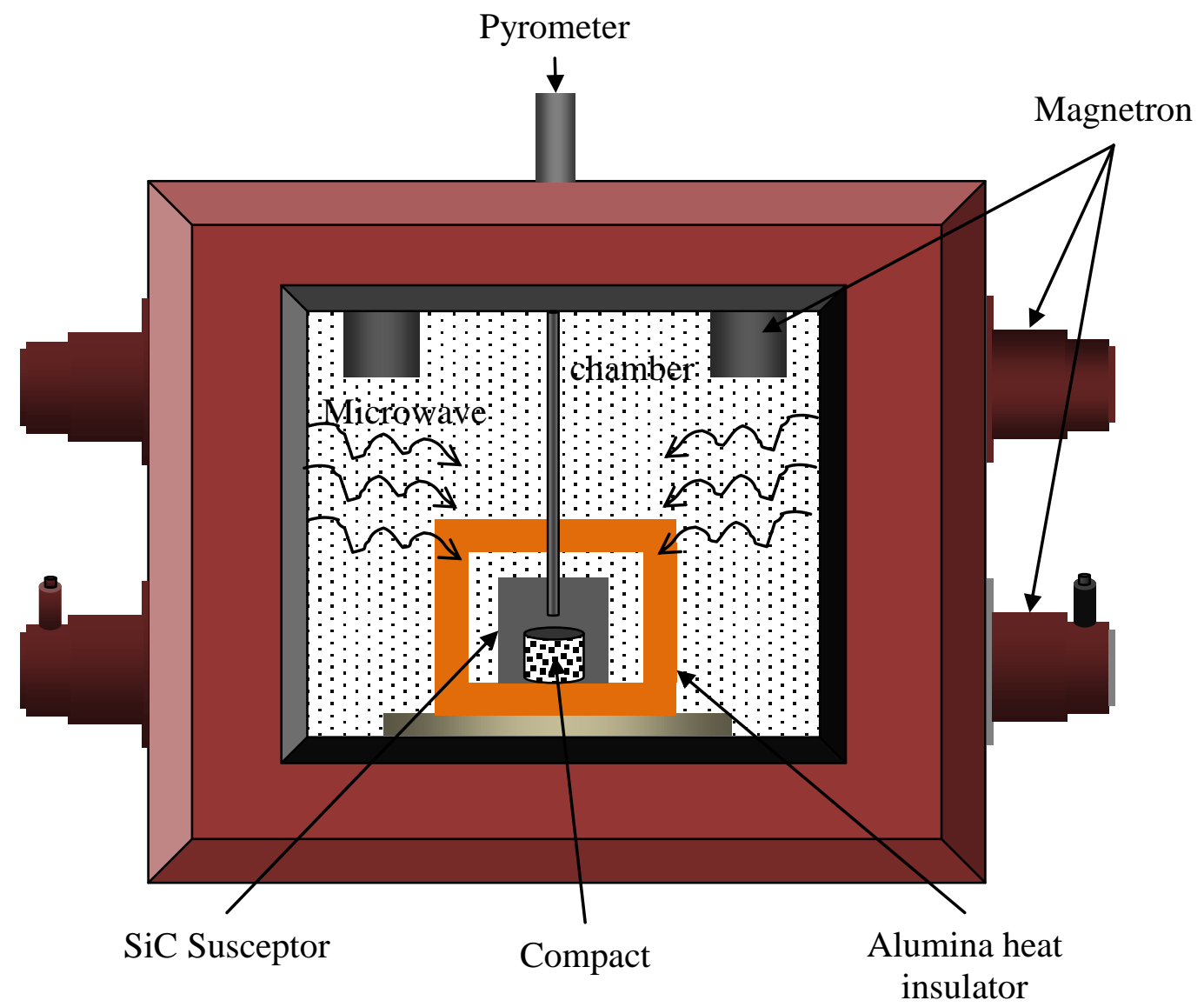

Fig. 2. Schematic diagram of in-house developed experimental setup of rapid microwave sintering process. 


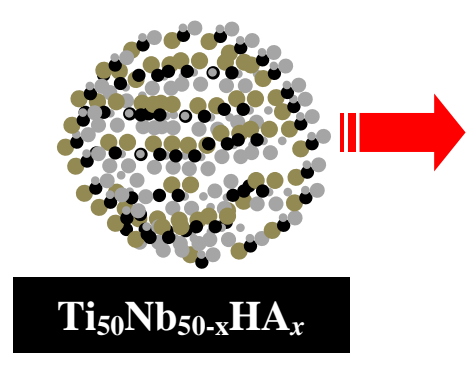

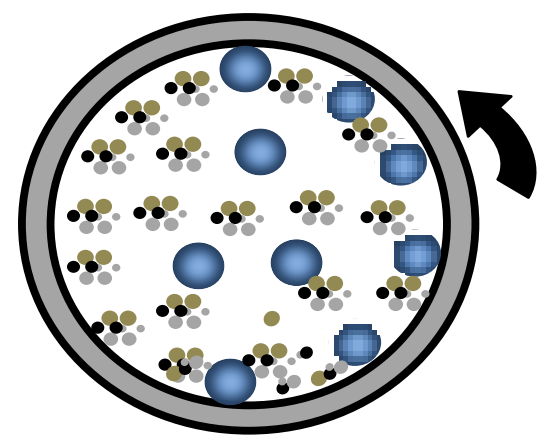

Mechanical Alloying

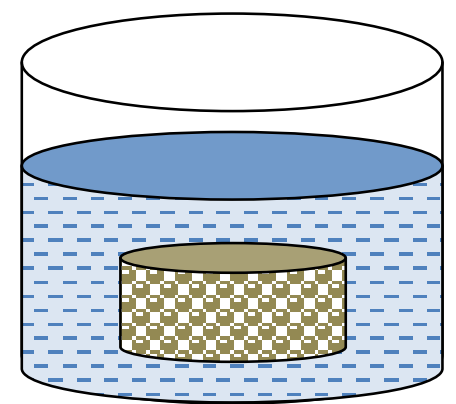

De-alloying of space holder

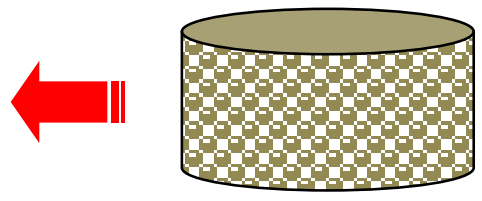

\section{Green compact}

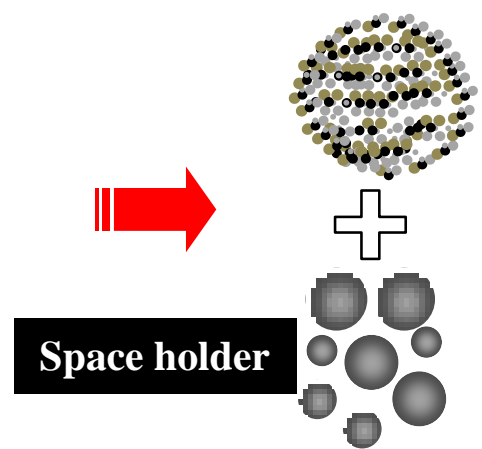

Mixing with space holder
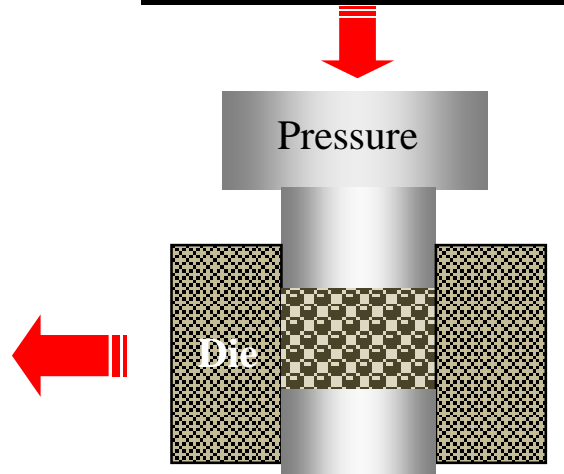

Pressure

Compacting of powder mixture

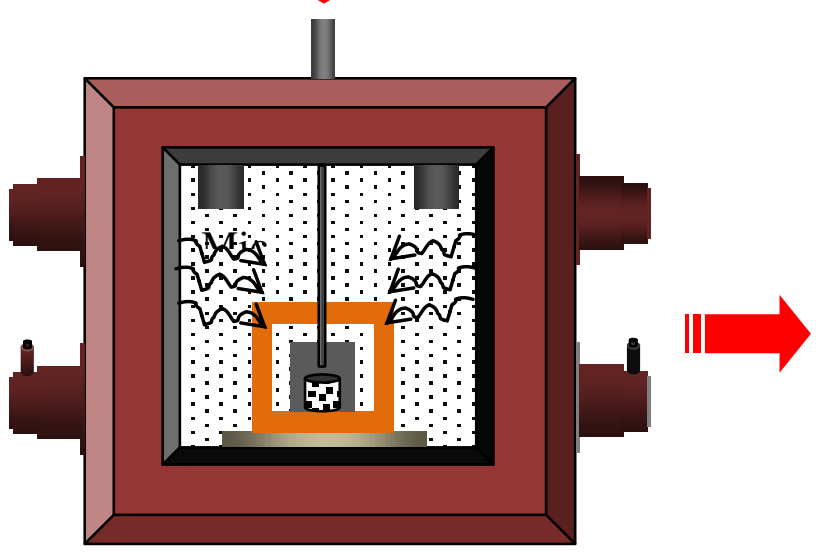

Rapid Microwave sintering

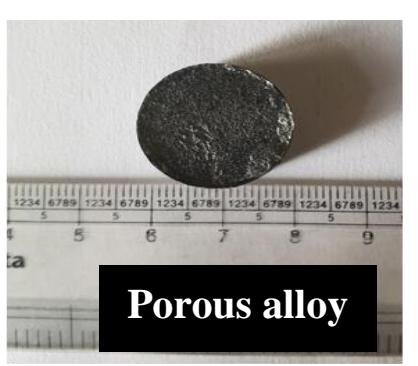

Sintered compact

Fig. 3. Fabrication route for porous Ti-Nb-HA composites 

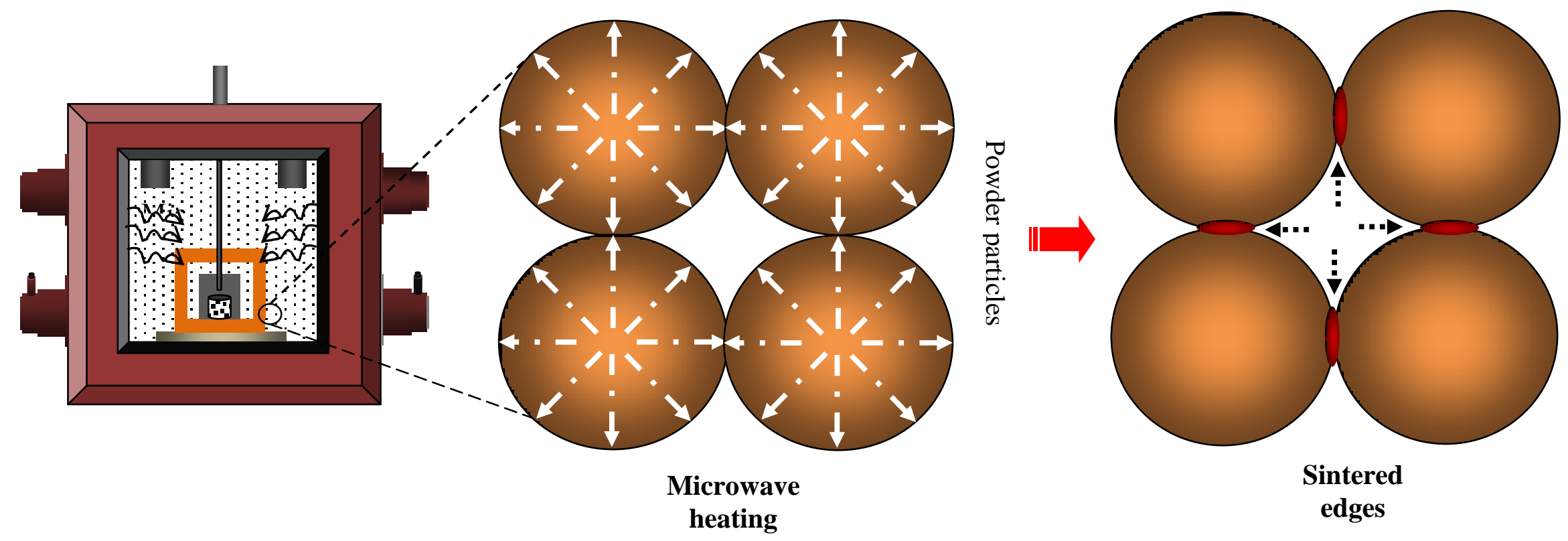

Fig. 4. Mechanism of microwave sintering process 


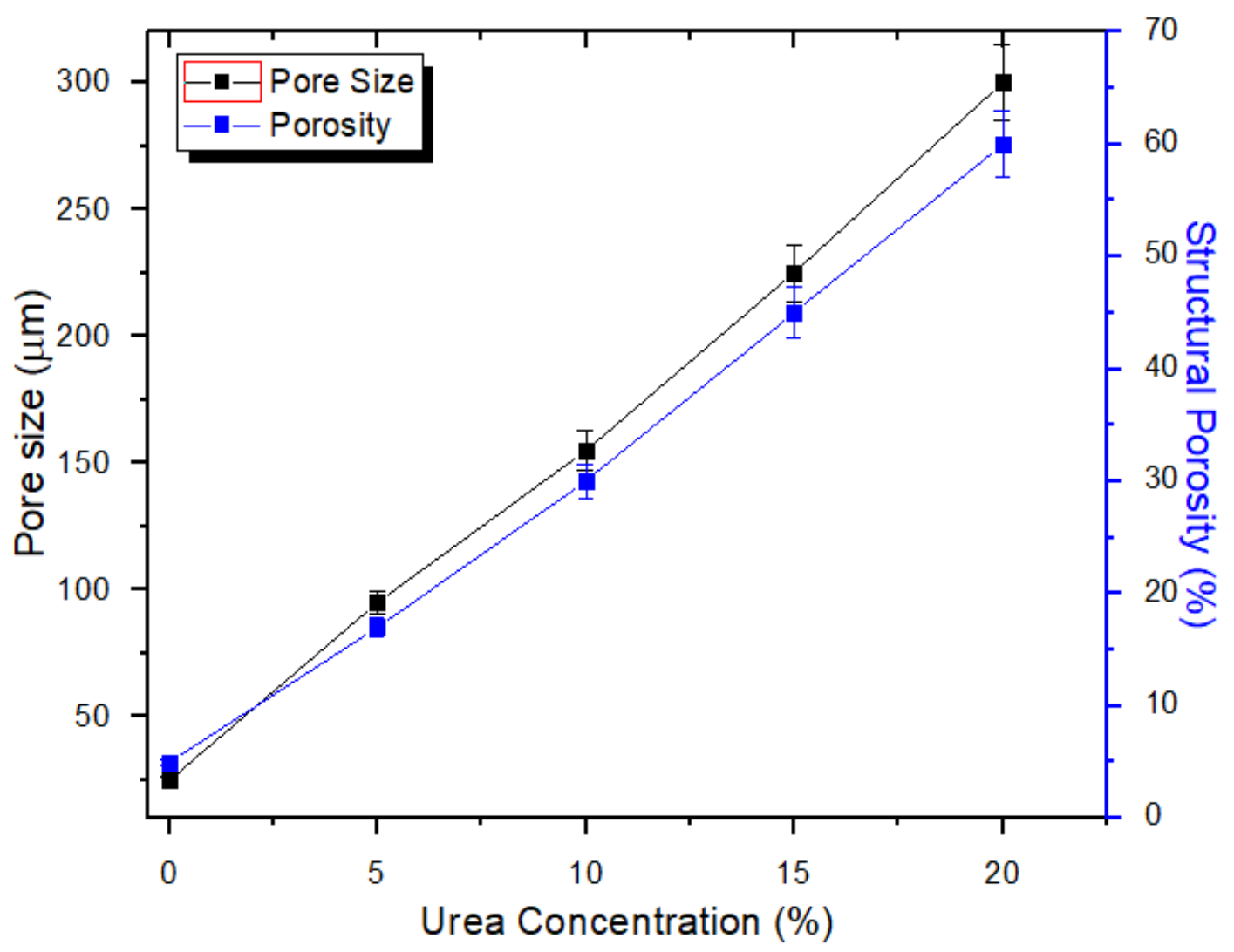

Fig. 5. Average pore size and structural porosity of the porous Ti-Nb-HA composites with different contents of urea 

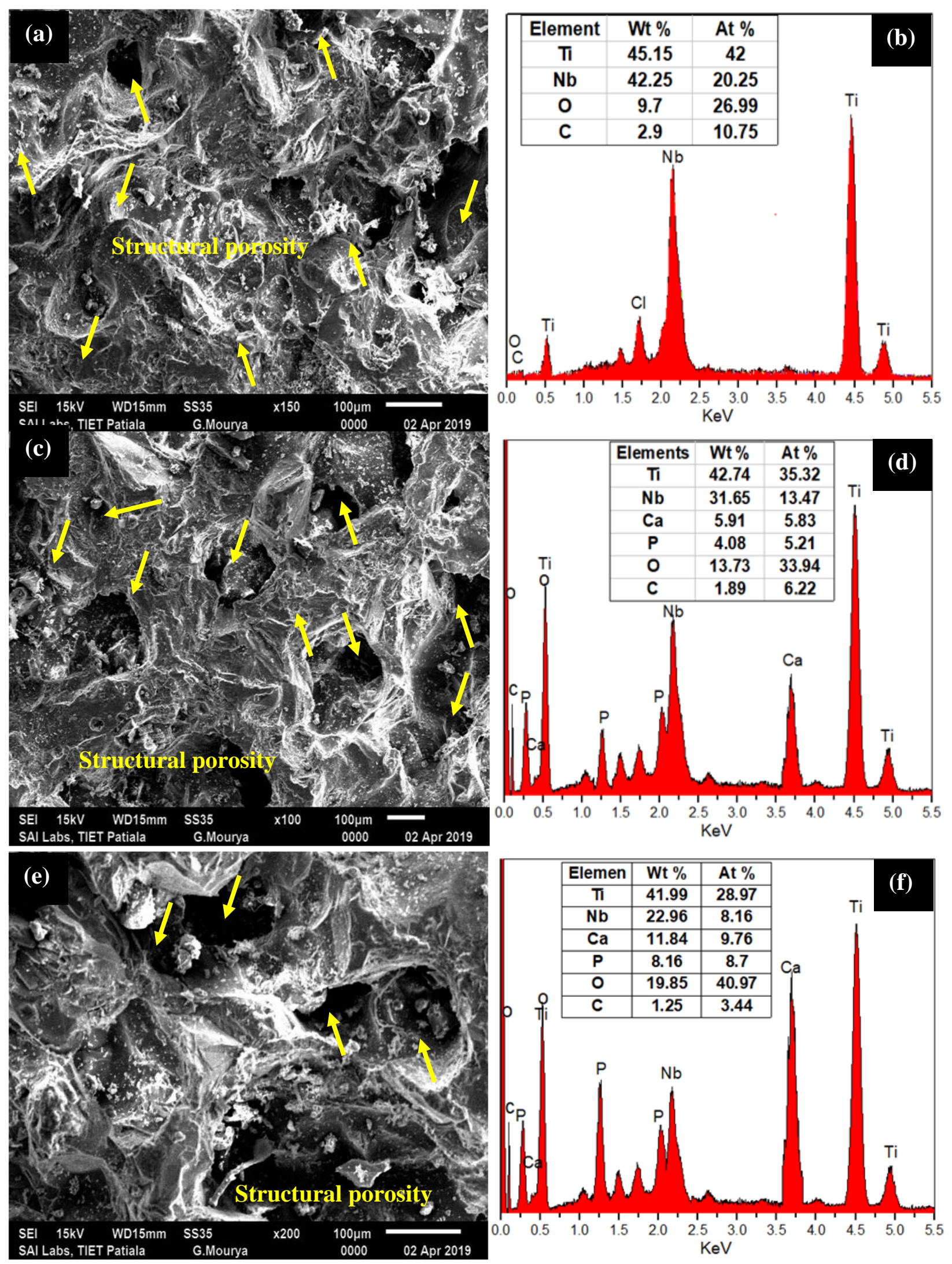

Fig. 6. SEM and EDS spectrum of sintered Ti-Nb-HA $(x=0,10,20)$ composites 


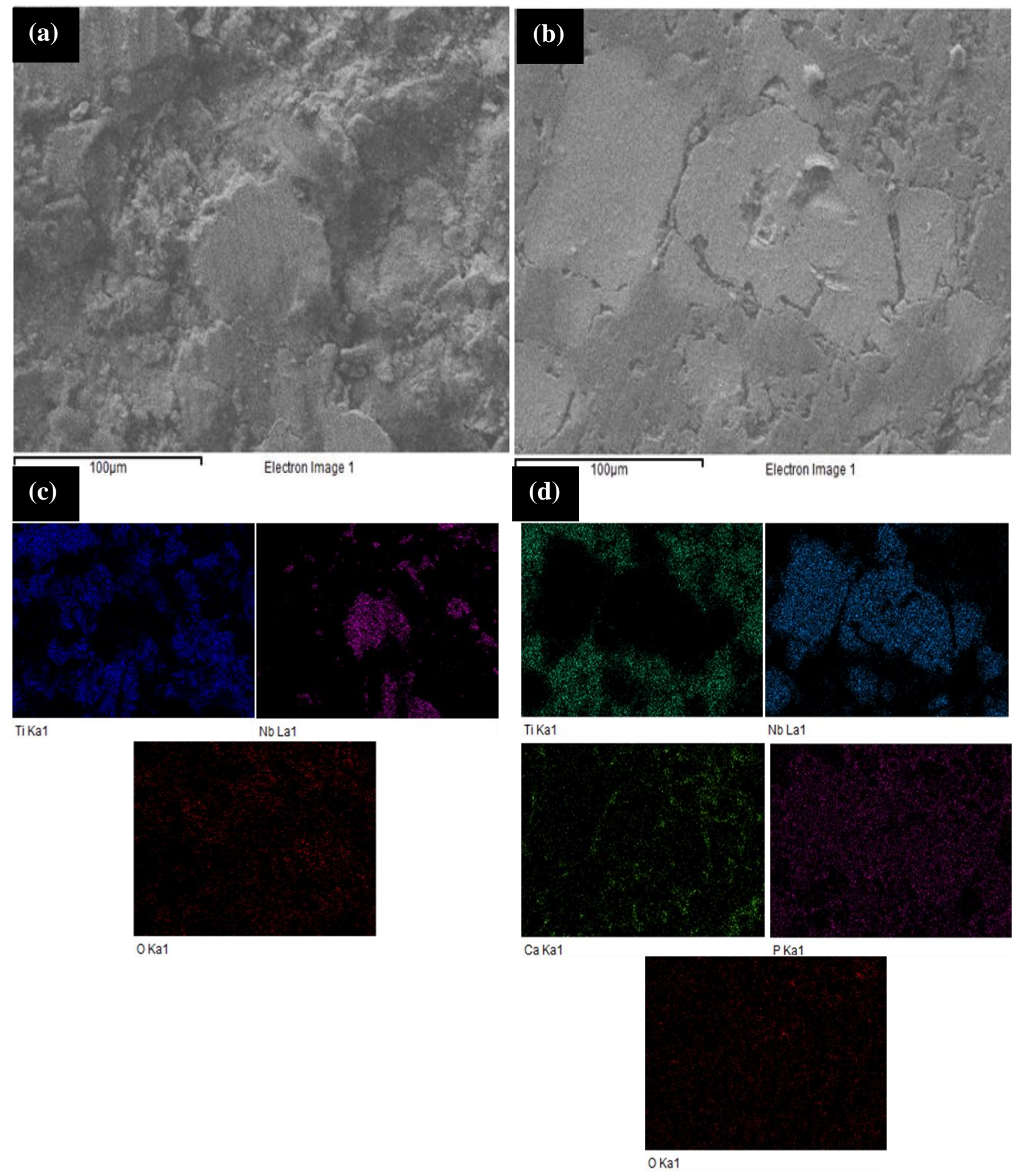

Fig. 7. EDS mapping of sintered $\mathrm{Ti}-50 \mathrm{Nb}$ and $\mathrm{Ti}-30 \mathrm{Nb}-20 \mathrm{HA}$ composite 


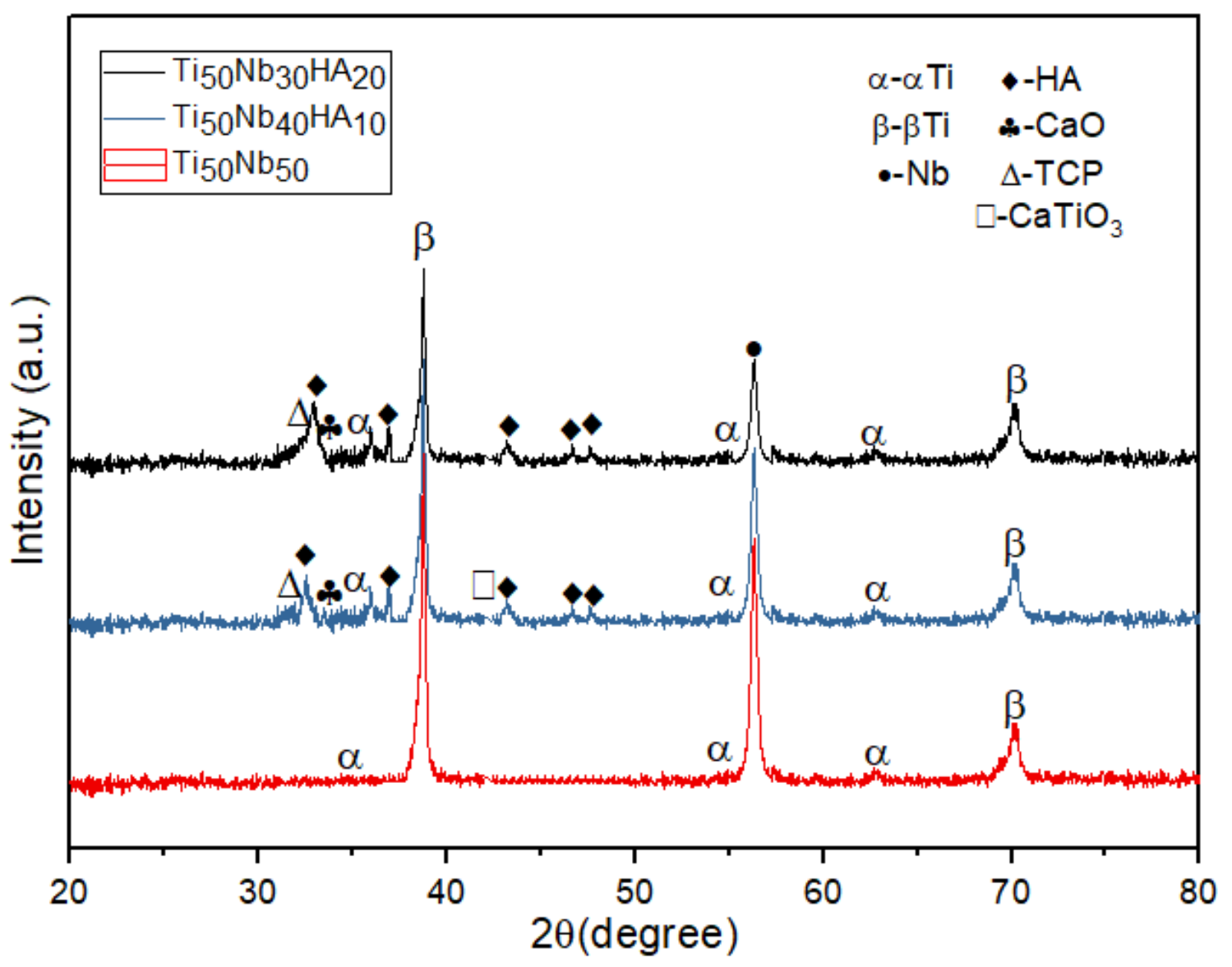

Fig. 8. XRD pattern of sintered Ti-Nb, Ti-40Nb-10HA, and Ti-30Nb-20HA composites 


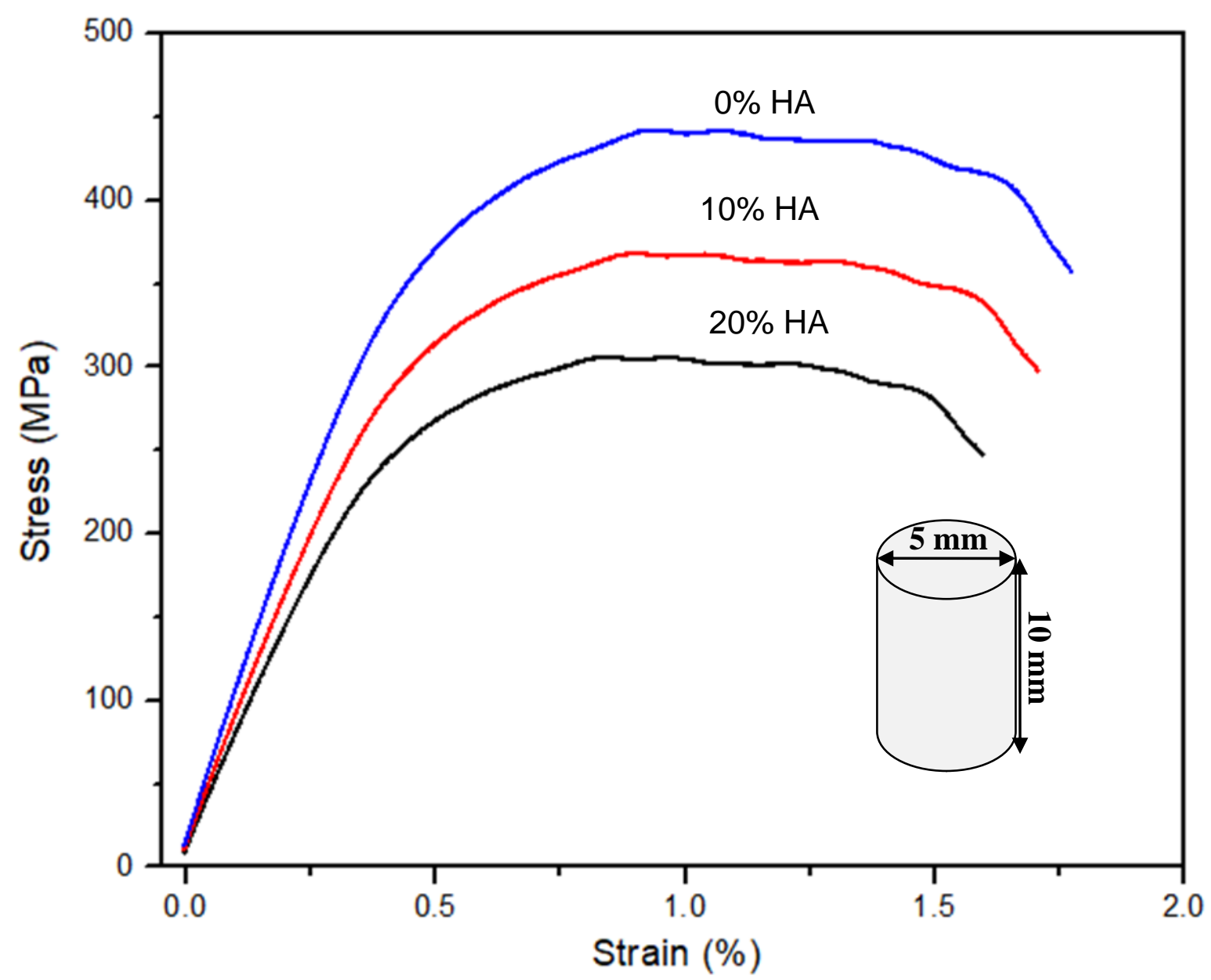

Fig. 9. Compressive curves of the porous Ti-Nb-HA composites at different concentration of HA $(0,10$, and $20 \%)$ 


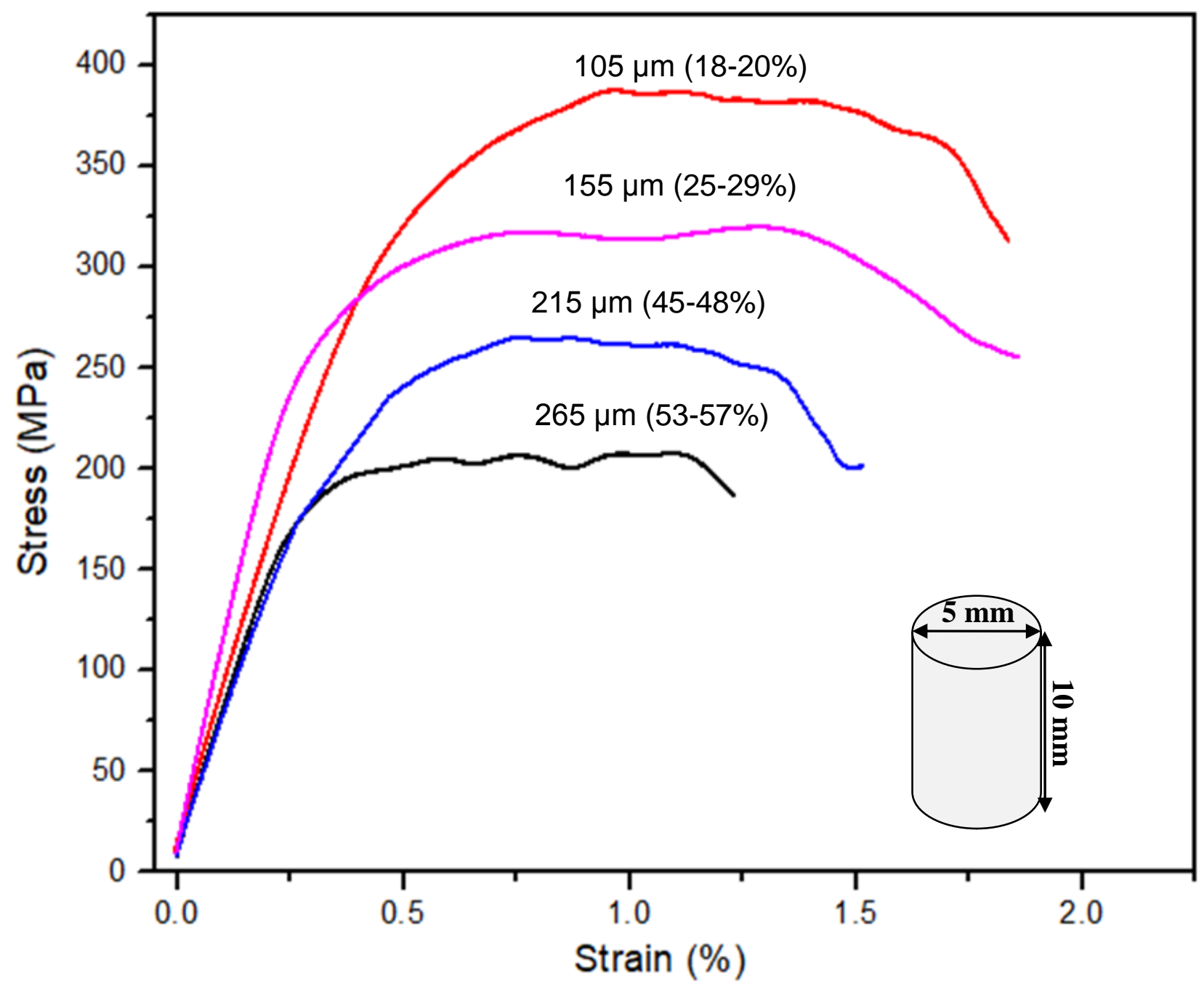

Fig. 10. Compressive curves of the porous Ti-Nb-HA composites at different pore sizes and structural porosity 


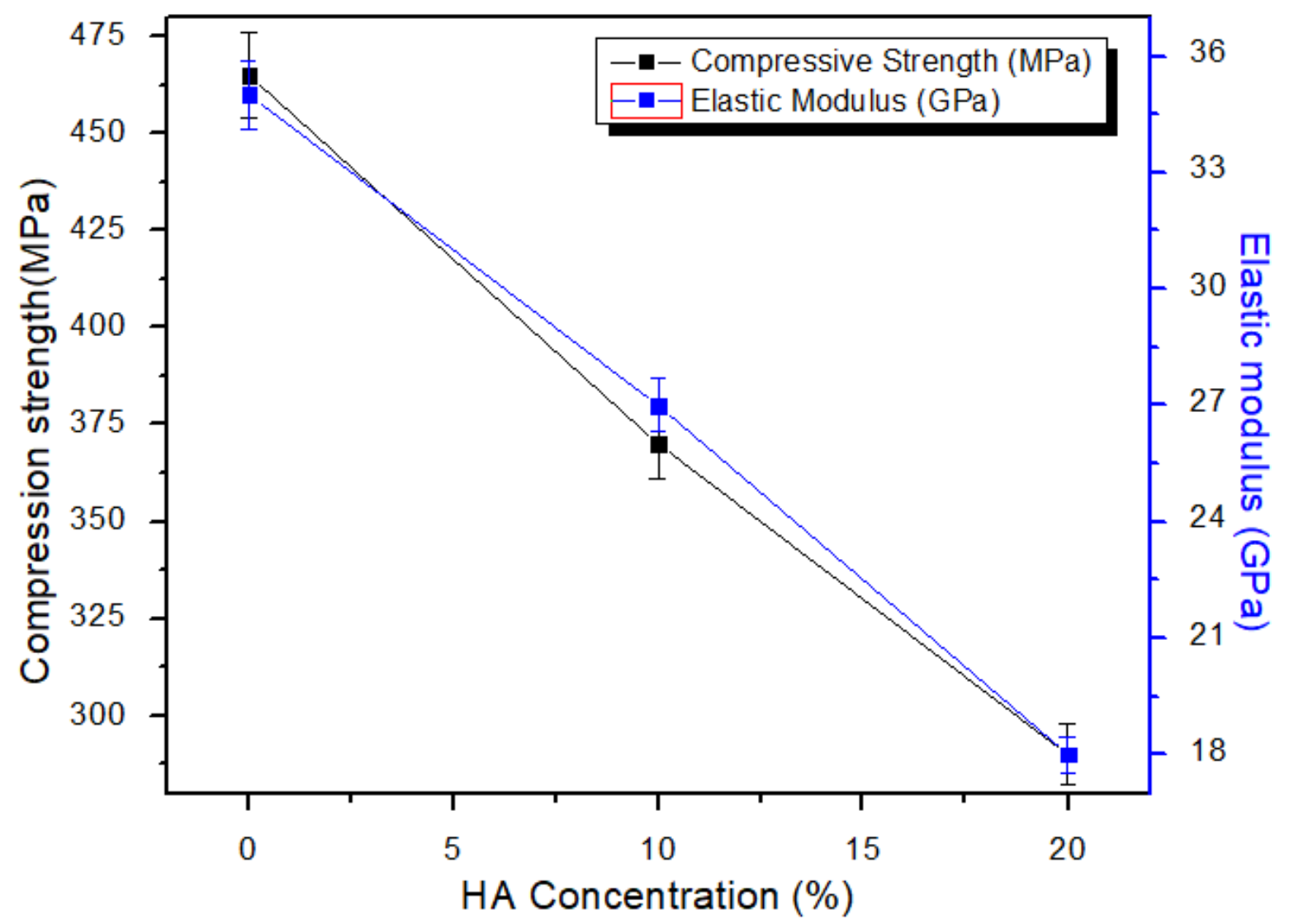

Fig. 11. Effect of HA concentration and compressive strength and elastic modulus of the porous Ti-Nb-HA composite 


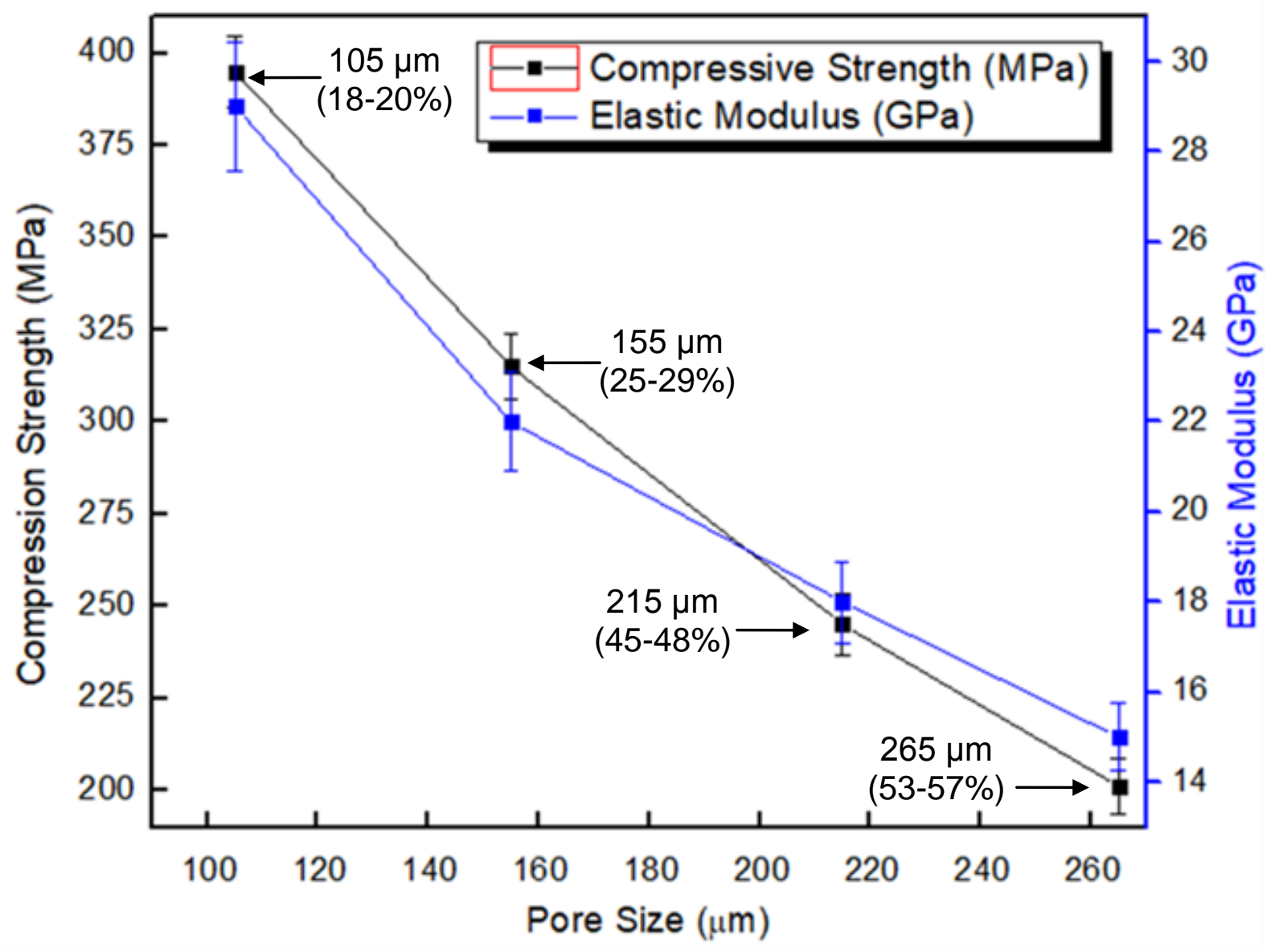

Fig. 12. Effect of pore sizes on compressive strength and elastic modulus of the porous Ti-NbHA composite 


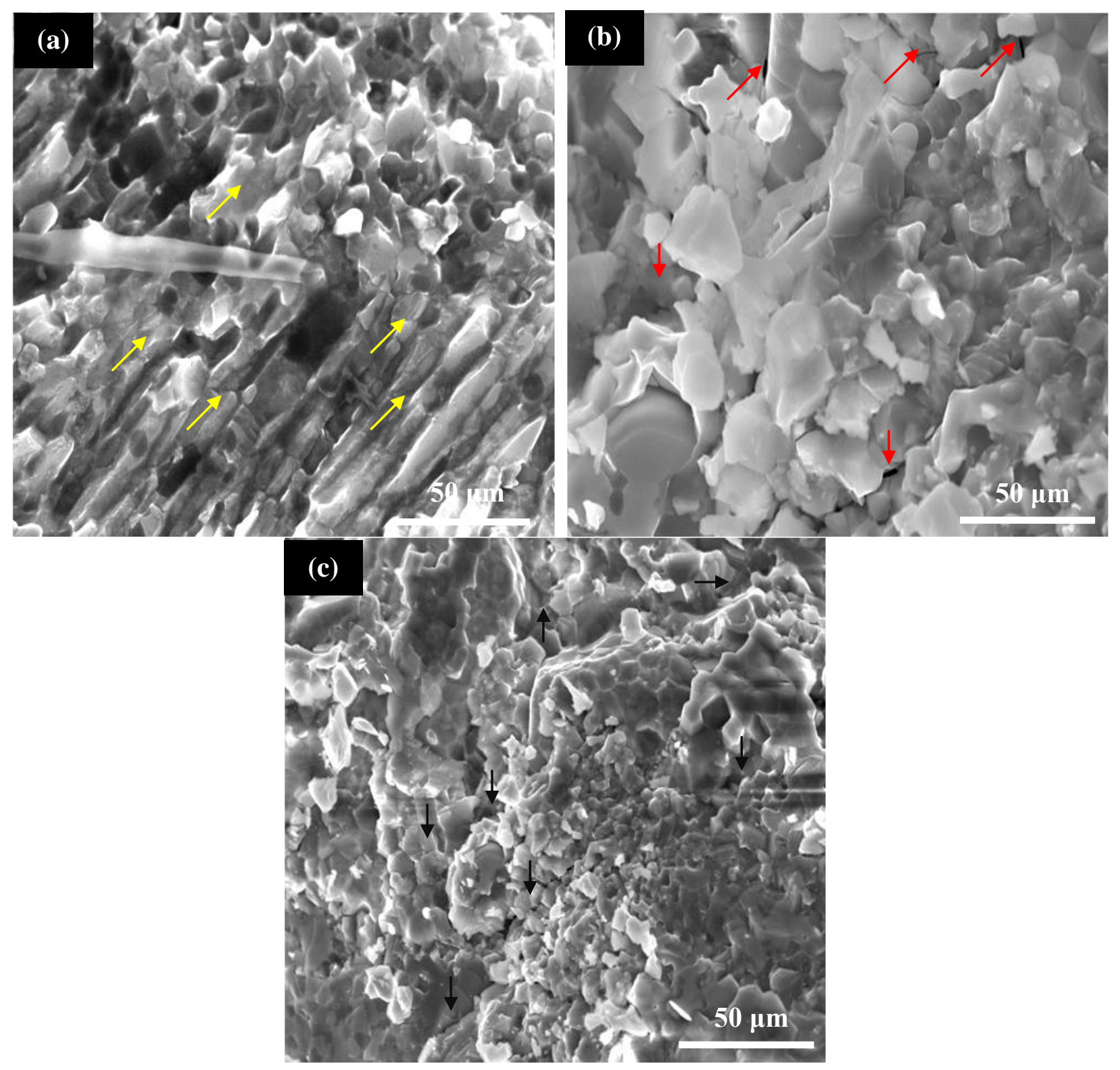

Fig. 13. SEM fractographs of porous composites after compressive test: (a) porous Ti-50\% $\mathrm{Nb}$; (b) porous $\mathrm{Ti}-40 \mathrm{Nb}-10 \mathrm{HA}$; and (c) porous $\mathrm{Ti}-30 \mathrm{Nb}-20 \mathrm{HA}$. 


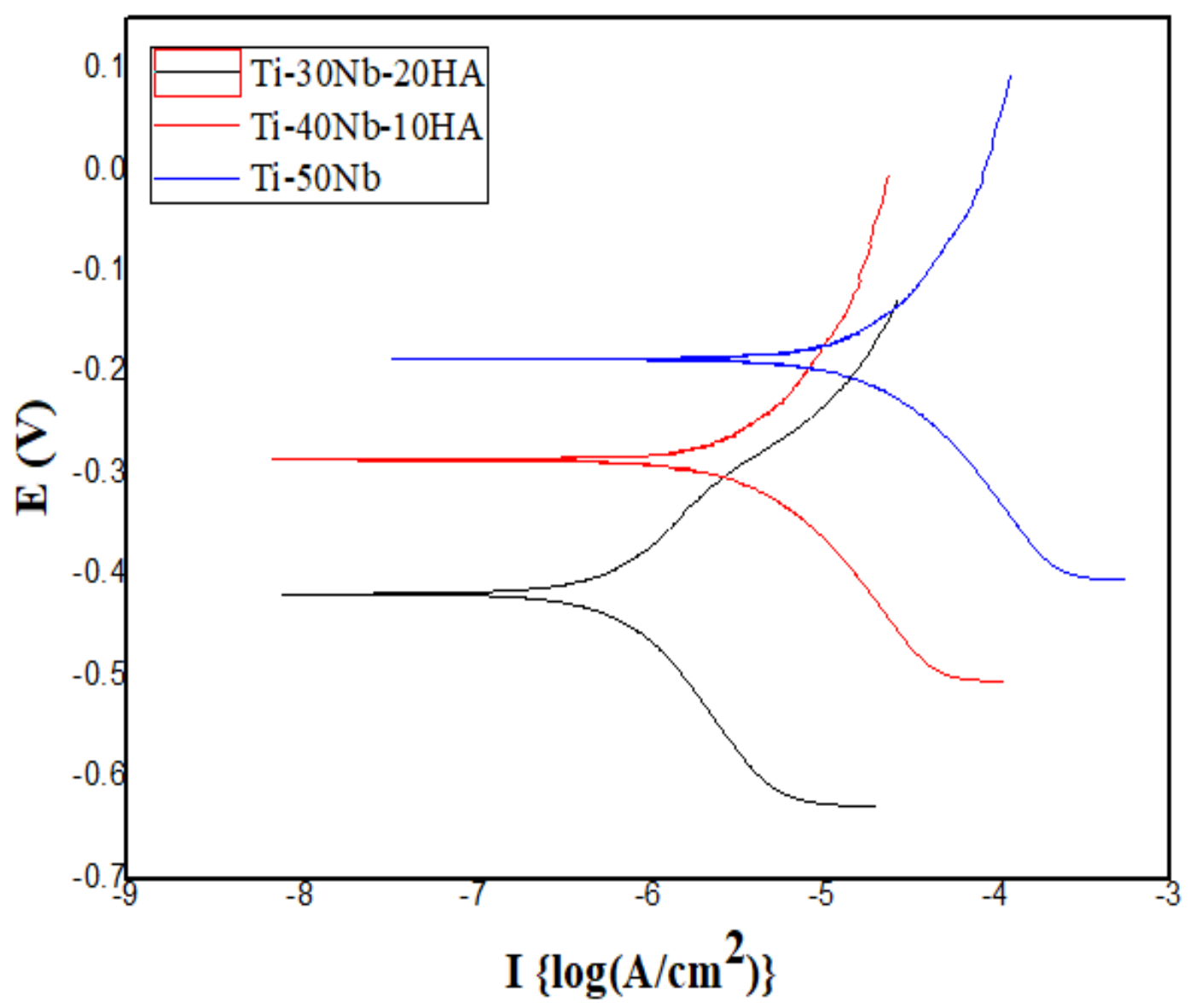

Fig. 14. Potentiodynamic polarization curves of as-sintered Ti-Nb-HA composite measured in SBF (Ringer's Solution) at $37 \pm 1^{\circ} \mathrm{C}$. 

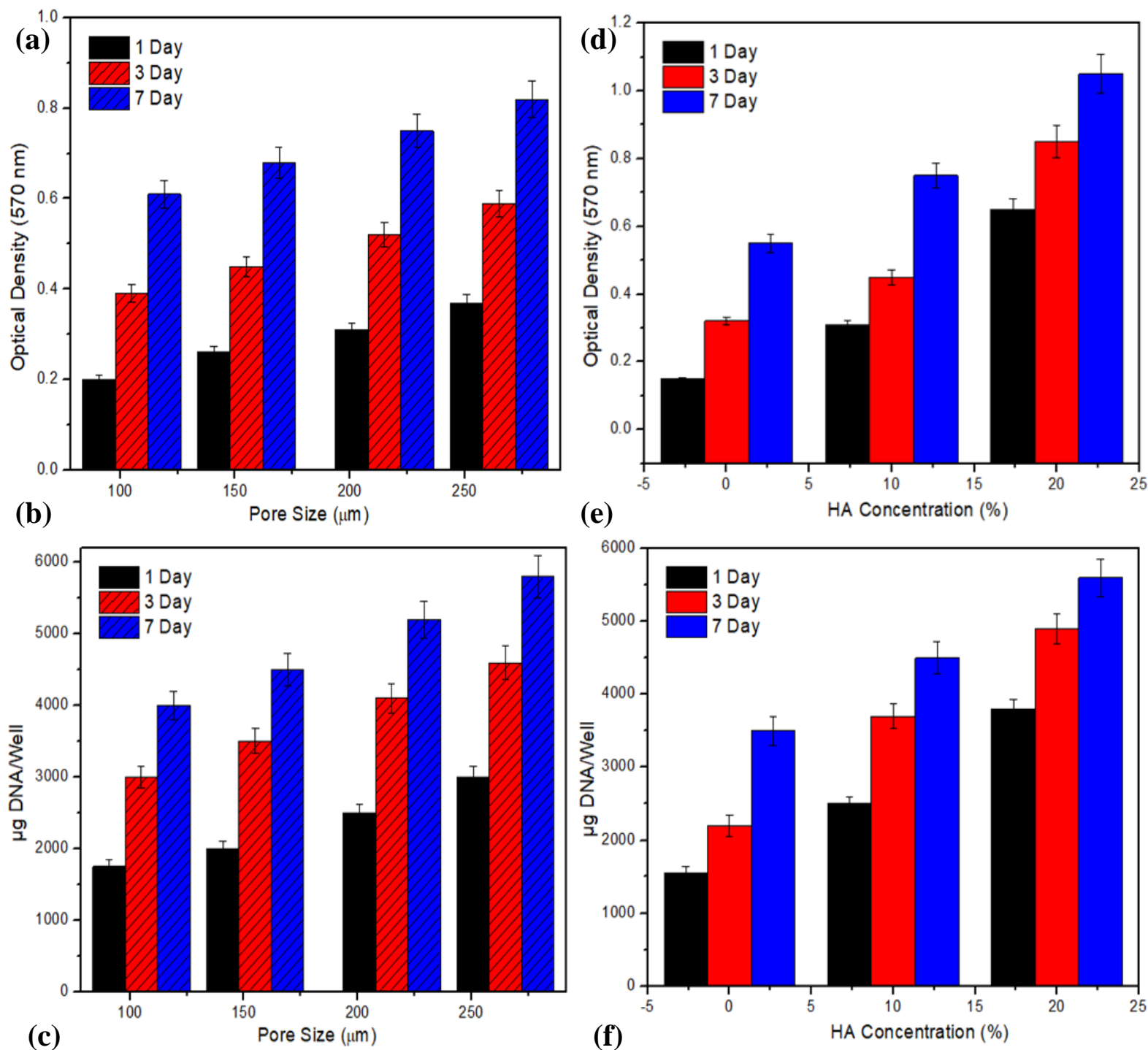

(e)

HA Concentration (\%)
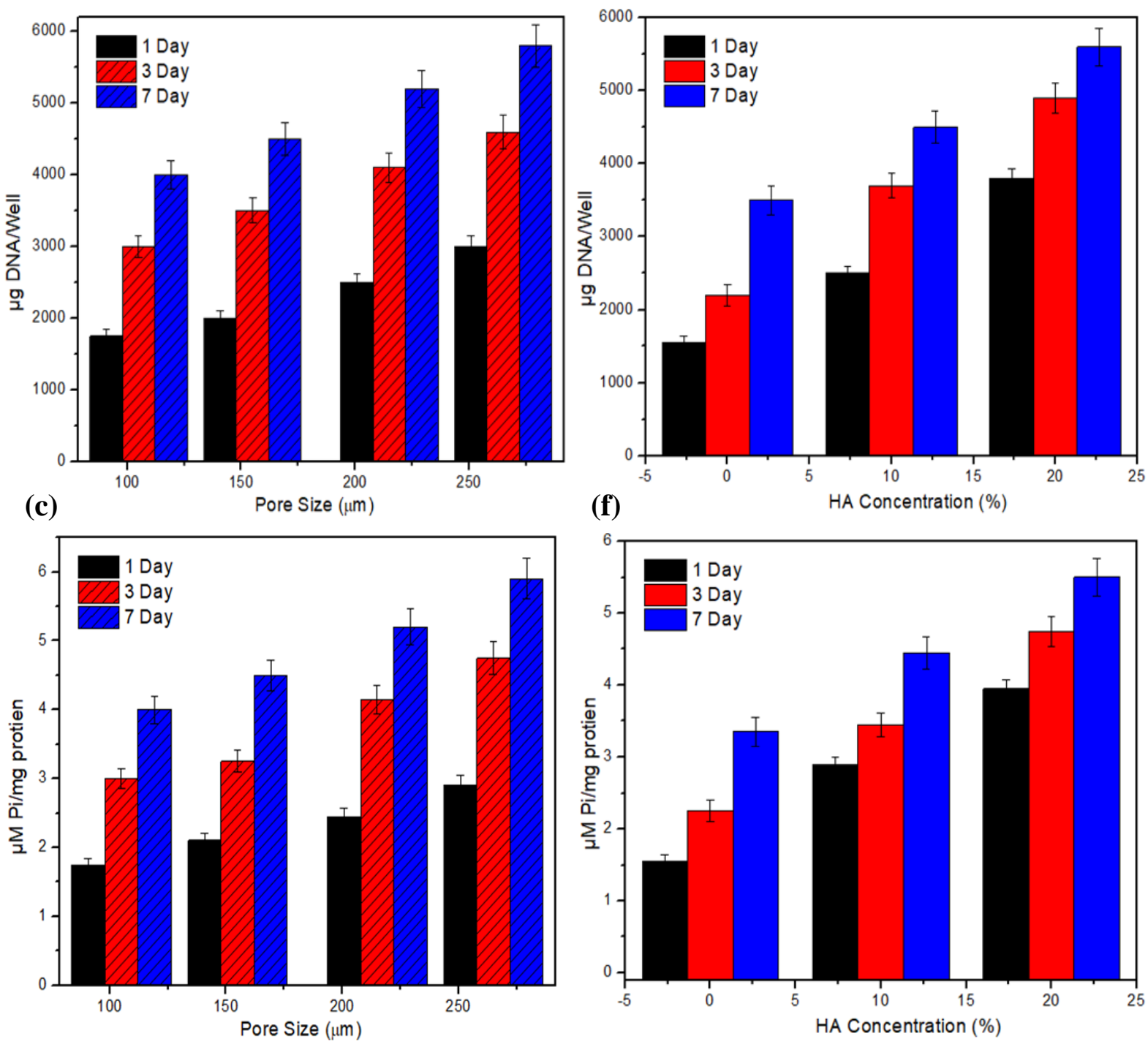
Fig. 15. Effect of pore size (a-c) and HA concentration (d-f) on cell proliferation and differentiation of MG- 63 cells determined on day $1^{\text {st }}, 3^{\text {rd }}$, and $7^{\text {th }}$ after seeding on porous Ti-NbHA composites: (a-d) MTT assay, (b-e) DNA content, and (c-f) ALP activity 


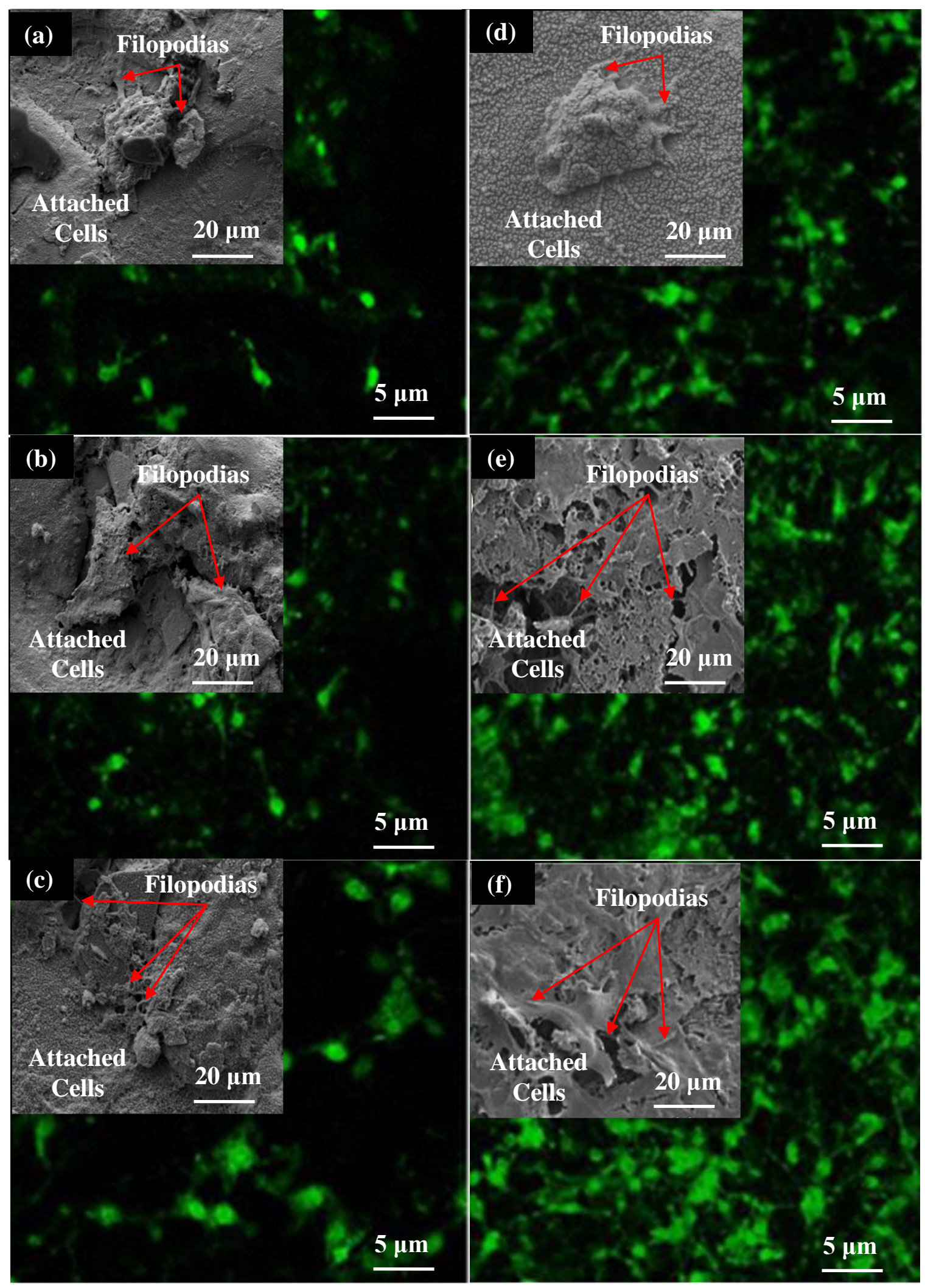

Fig. 16. The cells growth on as-sintered porous Ti-Nb-HA composites after 1 and 7 days 


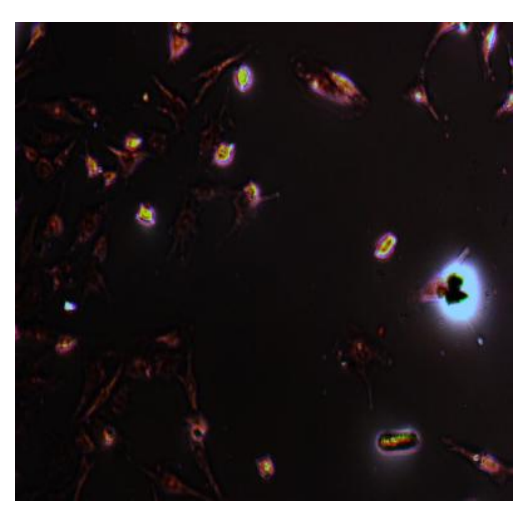

Cells on Ti-Nb composite

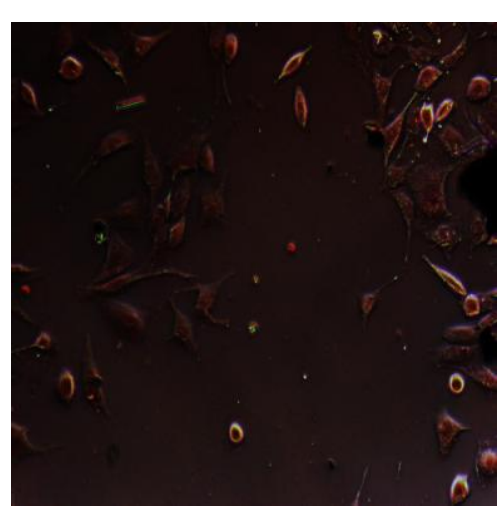

Cells on Ti-40Nb-10HA composite

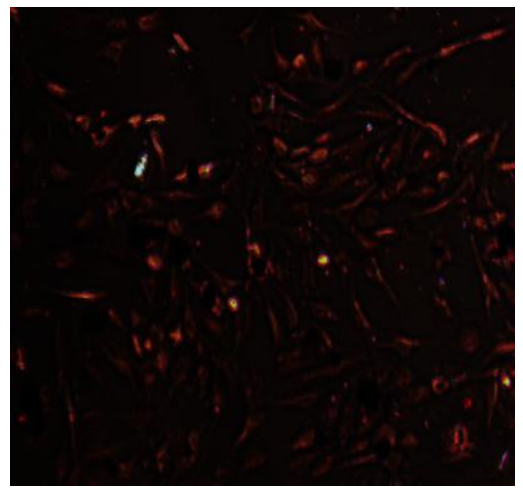

Cells on Ti-30Nb-20HA composite

Fig. 17. Alizarin red staining: red stained cells show accumulation of calcium content 